\title{
CORRUPCIÓN EN EL SECTOR PRIVADO (I): LA CORRUPCIÓN PRIVADA Y EL DERECHO PRIVADO PATRIMONIAL
}

\author{
Fernando Carbajo Cascón \\ Doctor en Derecho, Universidad de Salamanca, España; Licenciado en Derecho de la Universidad de Salamanca \\ España; Magistrado de la Audiencia Provincial (Corte de Apelación) de Salamanca. \\ Profesor Titular de Derecho Mercantil de la Universidad de Salamanca, España. \\ Correo electrónico:nano@usal.es
}

\begin{abstract}
Resumen
El presente trabajo sobre la corrupción en el sector público a la corrupción en el sector privado, expone al necesidad de una definición sobre el control de la corrupción privada en convenciones regional e internacionales, a su vez presenta la interrelación entre corrupción y derecho, en particular corrupción y derecho privado patrimonial. También se expone sobre las técnicas jurídico-privadas básicas para la comisión, encubrimiento y blanqueo de operaciones de corrupción. Finalmente, las medidas de prevención y represión de la corrupción, el papel de derecho privado en las medidas coercitivas en el plano administrativo y privado, mecanismos penales, administrativos y jurídico-privados.
\end{abstract}

Palabras Clave: Corrupción, corrupción privada, derecho privado patrimonial, prevención, represión.

\begin{abstract}
The present work on the corruption in the public sector to the corruption in the private sector, exposes the necessity of a definition on the control of the corruption deprived in regional and international conventions, in turn he presents the interrelationship between corruption and right, especially corruption and private patrimonial right. Also it is exposed on the juridical - private basic technologies for the commission, concealment and whitening operation of corruption. Finally, the measures of prevention and repression of the corruption, the paper of right deprived in the coercive measures in the administrative and private plane, penal, administrative and juridical - private mechanisms.
\end{abstract}

Keywords: Corruption, private corruption, private patrimonial right, prevention, repression.

\section{Résumé}

Le travail présent la corruption dans le secteur public à la corruption dans le secteur privé, expose à la nécessité d'une définition sur le contrôle de la corruption privée dans des conventions régionales et internationales, à son tour présente la relation entre une corruption et un droit, en particulier une corruption et un droit privé patrimonial. Il s'expose aussi sur les techniques juridiques - privées basiques pour la commission, une dissimulation et un blanchiment d'opérations de corruption. Finalement, les mesures de prévention et répression de la corruption, le papier de droit privé dans les mesures coercitives dans le plan administratif et privé, les mécanismes pénaux, administratifs et juridiques - privés.

Mots-clés: Une corruption, une corruption privée, un droit privé patrimonial, une prévention, une répression. 

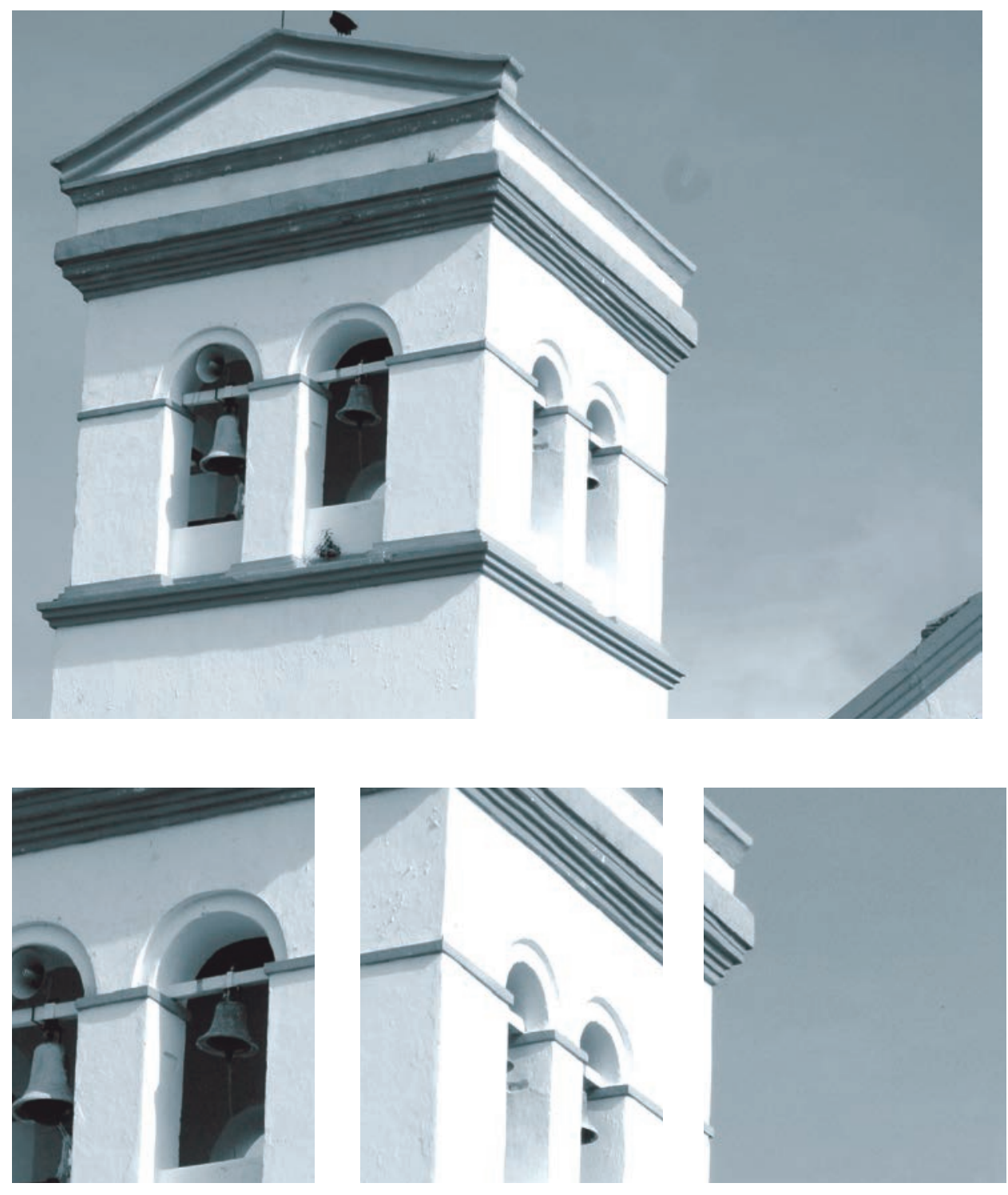

Iglesia de Santa Bárbara - Mompóx - Colombia

Martín Emilio Hernández Manrique 


\section{CORRUPCIÓN EN EL SECTOR PRIVADO (I): LA CORRUPCIÓN PRIVADA Y EL DERECHO PRIVADO PATRIMONIAL*}

Fernando Carbajo Cascón

\section{De la corrupción en el sector público a la corrupción en el sector privado}

El sustrato tradicional y habitual de la corrupción gira en torno a la actividad económica de la Administración; a la atribución de potestades de decisión, control y aplicación de fondos públicos a cargos políticos, funcionarios y personal contratado. La corrupción en el sector público surge, como tal, con motivo de las relaciones ilícitas o fraudulentas de esos cargos políticos electos y del personal de las Administraciones públicas con intereses económicos privados, propios o ajenos, que persiguen la maximización del lucro empresarial y personal a costa de los intereses generales.

Desde esta perspectiva clásica, la corrupción supone una utilización desviada, desleal o perversa de potestades públicas para satisfacer intereses privados o particulares del titular de esas potestades y/o de uno o varios terceros relacionados con él mediante relaciones económicas ilícitas (sobornos) o mediante relaciones de confianza (relaciones familiares y de amistad, pactos fiduciarios), que menoscaban la satisfacción objetiva de los intereses generales y contrariando la cláusula constitucional del Estado Social de Derecho, según la cual todos los intereses privados quedarán supeditados al interés general de la nación ${ }^{1}$.

En la base del fenómeno socioeconómico de la corrupción está el problema

El presente texto se produce en el contexto del proyecto: Corrupción en el sector privado, en el marco del convenio de colaboración, Universidad de Salamanca España - Universidad Santo Tomás Bucaramanga, - Grupo de Investigación Neoconstitucionalismo y Derecho, 2011.

1 Vid. sobre la compleja y abstracta noción de interés público y sobre la corrupción como desviación del fin de realización de los intereses generales, CUGAT MAURI, M. La Desviación del Interés General y el Tráfico de Influencias, Cedes, Barcelona, 1997, pp. 36 y ss. 
eterno de los conflictos de intereses entre intereses públicos o generales ${ }^{2}$ e intereses privados que se interponen a aquellos ${ }^{3}$, aprovechando comportamientos desviados de los titulares de potestades públicas ${ }^{4}$. Esa utilización desviada de potestades públicas puede ser decisión propia (espontánea o premeditada) de quienes tienen competencias de gestión y representación de Administraciones y entes públicos ${ }^{5}$, pero también puede venir provocada o fomentada por un tercero ajeno a la Administración que pretende prevalerse del poder de decisión de gestores y representantes públicos ofreciendo a cambio dádivas o ventajas económicas o de otro tipo, distinguiéndose así en términos amplios entre corrupción activa y corrupción pasiva (el que soborna y el sobornado). La corrupción puede ser ocasional o continuada, circunstancia en la que se aprecian situaciones de redes de corrupción organizada de muy diversa naturaleza y fines.

El fenómeno de corrupción se sustancia, por tanto, en la interposición de un interés privado sobre el interés público o general. La actividad económica de la Administración atrae poderosamente intereses privados, generalmente de naturaleza económica (de hecho, una parte importante de la actividad económica privada está relacionada con las actividades de las dministraciones públicas, por ejemplo, en las concesiones de obras y servicios públicos o en el suministro de bienes de equipo y en la prestación de servicios de muy distinta naturaleza a las instituciones públicas), que provocan o fomentan conductas desleales con los intereses públicos o generales por parte de políticos y funcionarios y por parte de aquellos sujetos privados que establecen o quieren establecer relaciones económicas con una Administración.

Así pues, desde esta perspectiva tradicional del fenómeno de la corrupción se aprecia la alineación de componentes económicos o financieros públicos y privados, con la intención última manifiesta de hacer prevalecer lo privado sobre lo público. El beneficio de la corrupción (tangente) ${ }^{6}$ es, en suma, para políticos, funcionarios y empleados públicos corruptos $\mathrm{y}$, en su caso, para empresas y particulares que

2 A partir de una noción realista de interés general, público o colectivo como denominador común de los intereses particulares de los ciudadanos expresado a través de las instituciones y los procedimientos públicos.

3 Sobre el conflicto de intereses públicos y privados como esencia de la corrupción, vid. la obra de GARCÍA MEXÍA, P. Los Conflictos de Intereses y la Corrupción Contemporánea, Aranzadi, Colección Divulgación Jurídica, Navarra, 2001.

4 Sobre la noción de comportamientos desviados y corrupción, vid., FAVA, T. Do ut des (Genesi, evoluzione e crisi del sistema della corruzione), Carocchi, Roma, 1999, pp. 30 y ss.

5 El cual, a su vez, puede actuar de forma aislada o formar parte de un entramado fraudulento que contamina una determinada organización o institución. Para la diferencia entre corrupción subjetiva y objetiva vid. D’ALBERTI M., “Corruzione soggettiva e oggettiva”, en D’ALBERTI M Y FINOCCHI R., Corruzione e Sistema Istituzionale, Il Mulino, Bologna, 1994, pp. 13 y ss.

6 La "tangente" es la denominación italiana del beneficio ilícito, ya generalizada en todo el mundo. Vid. ZANCHETTA, P.L. "Tangentopoli: entre perspectivas políticas y judiciales”, en ANDRÉS IBÁÑEZ, P.A. (Edit.), Corrupción y Estado de Derecho. El papel de la jurisdicción, Madrid, 1996, pp. 85 y ss. 
obtienen un lucro en su patrimonio empresarial o personal para evitar las exigencias y formalidades exigidas por la Administración y los costes propios de la competencia en una economía de mercado ( $v . g r$. el coste que supone la participación en concursos públicos de adjudicación de obras o servicios públicos en régimen de libre competencia e igualdad de oportunidades ante la Administración, tal y como exigen los intereses generales).

Por otro lado, como es natural, la corrupción produce una pérdida de recursos económicos y de confianza que afecta directa o indirectamente al funcionamiento eficiente de la Administración y lesiona la imagen de ésta ante los ciudadanos, erosionando la confianza en el Estado de Derecho e incluso en el mismo sistema político de referencia ${ }^{7}$. Ello además, sin olvidar otros grupos de intereses privados concretos (como pueden ser los de los competidores en el mismo mercado del sujeto beneficiado por un acto de corrupción $)^{8}$ y grupos de intereses intermedios (asociaciones de intereses empresariales, como son las corporaciones empresariales y de profesionales liberales, organizaciones no gubernamentales, etc.) e incluso intereses difusos (como puede ser el de los consumidores o el de los ciudadanos administrados en general) que también pueden verse afectados por un comportamiento corrupto.

Hasta aquí nada nuevo: corrupción como desviación ilícita del interés público en beneficio de intereses privados. Ahora bien, en la Sociedad actual, impregnada de elementos economicistas y de mercado en todos los sectores y escalas del cuerpo social, desde las actividades de producción y distribución hasta las de ahorro y consumo, y donde el sistema financiero en sus diferentes vertientes (crédito, valores y seguros) adquiere una importancia más que significativa en la vida diaria de los ciudadanos (habitualmente se caracteriza al hombre de los siglos XX y XXI como un "homo economicus"), el fenómeno de la corrupción no puede considerarse exclusivo

7 Vid. HEIDENHEIMER, A.J./JOHNSTON, M./ LEVINE, V.T. (Edits.), Political Corruption. A Handbook, Transaction, New Brunswick, 1989, pgs. 5 y 6. Citado por CUGAT MAURI, $L a$ Desviación..., cit., p. 55, para quien "el concepto de corrupción va unido íntimamente al concepto de crisis puesto que como en ésta, el mal funcionamiento es imputable a disfunciones internas del sistema".

8 Vid. FAVA, Do ut des..., cit., pp. 62 y ss., que califica el mercado de la contratación pública como un mercado de la corrupción, por constituir el principal terreno donde se establecen las relaciones entre empresa privada y poder público que constituyen el caldo de cultivo de la corrupción; un mercado, además, donde quiebra el principio de libre competencia que caracteriza la economía de mercado.

Conviene reseñar, no obstante, que, alentados por Acuerdos y Convenios Internacionales en materia de corrupción, en los últimos años los países desarrollados del área de la Unión Europea han promulgado normativas para alcanzar la máxima transparencia e igualdad de oportunidades en la contratación pública y garantizar así la libre competencia en el acceso a las ofertas de contratación de obras y servicios públicos. Vid. a modo de ejemplo, en el ordenamiento jurídico español, la Ley 30/2007, de 30 de octubre, de Contratos del Sector Público, que fija como principales objetivos, en su Exposición de Motivos, establecer exigencias procedimentales, garantías para el licitador, y preservación de los principios de publicidad, concurrencia y transparencia. 
del ámbito público, esto es, de las Administraciones y Empresas públicas.

Los graves escándalos ocurridos en los últimos años en los mercados financieros y en grandes empresas (la mayoría en forma de sociedades anónimas cotizadas) de distintas partes del mundo (muchas de ellas de proyección internacional, si no implantación multinacional), como los tristemente célebres casos Enron y Parmalat, incluidos algunos sonados desenfrenos en Organizaciones Internacionales (v.gr., el Comité Olímpico Internacional o la Organización Mundial del Comercio) y en el llamado tercer sector (formado por organizaciones no gubernamentales, asociaciones y fundaciones sin aparente ánimo de lucro), han generado una ola de desconfianza y malestar de los ciudadanos en las grandes empresas, en las instancias del poder político de control de los mercados e incluso en el mismo sistema económico de referencia mundial (el sistema capitalista de economía de mercado, controlado mediante la acción del Estado Social y Democrático de Derecho), a la vista de las graves consecuencias que tales escándalos han traído consigo para el funcionamiento eficiente del mercado y para la consecuente satisfacción de los intereses públicos o generales en el funcionamiento correcto del sistema de economía de mercado, así como, indirectamente, para los intereses particulares de los ciudadanos en sus condiciones respectivas o sucesivas de trabajadores, inversores, depositantes o impositores, asegurados o consumidores.

Es por eso que, en los últimos años, cobra cada vez más fuerza y sentido el análisis de la corrupción privada o corrupción en el sector privado, fruto de comportamientos desviados por parte de los centros de poder y decisión de las empresas privadas (administradores y cargos directivos laborales, como los apoderados, gerentes, directores generales o directores de área); empresas generalmente en forma de sociedad mercantil de capital (de ahí que en ocasiones se hable de corrupción

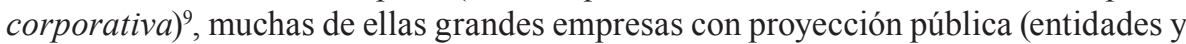
establecimientos financieros de crédito, empresas de servicios de inversión, sociedades cotizadas emisoras de valores, compañías de seguros y empresas concesionarias de obras y servicios públicos, entre otras). Estas desviaciones de intereses en la gestión de empresas privadas tienen lugar al aprovechar las lagunas legales y los defectos estructurales de las grandes compañías y del sistema financiero en su conjunto, en beneficio propio de los gestores o de personas relacionados con ellos por relaciones familiares, de amistad, de confianza o por simple interés económico, y en detrimento de otros intereses privados particulares y colectivos (por ejemplo los intereses de accionistas, inversores, trabajadores, acreedores, consumidores) y, a la postre, de los intereses generales cifrados en el funcionamiento eficiente del sistema financiero y económico en su conjunto.

9 Vid. PAMPLONA, A., "Corrupción corporativa y comportamiento oportunista: una perspectiva jurídica", accesible en el sitio http://www.contralacorrupcion.org/?p=29. 
En estos casos nos encontramos, entonces, con conductas fraudulentas en el ámbito privado (en el sentido de abusos de poder cometidos por los cesionarios o titulares de potestades de gestión y representación en la empresa privada, generalmente de estructura societario-capitalista, es decir, sociedades anónimas y sociedades de responsabilidad limitada) que perjudican a un número importante de intereses privados diferentes relacionados directa o indirectamente con un mismo ente privado (acreedores, trabajadores, accionistas, inversores, depositantes o ahorradores en general y otros) y, de manera refleja, lesionan el propio interés público en el funcionamiento eficiente del mercado, a la vista de la alarma social creada por estos escándalos financieros, sea por la pérdida de confianza en el sistema (es decir, en el entramado institucional y normativo que vela por la transparencia y el buen funcionamiento de los distintos mercados en términos de competencia), o sea por la necesidad de que la Administración intervenga directamente para evitar crisis financieras y empresariales, reflotar empresas en crisis y/o asumir el coste que suponen la pérdida masiva de puestos de trabajo y las pérdidas financieras de los ahorradores (cfr. prestaciones de desempleo, fondos de garantía salarial, fondos de garantía de depósitos y de inversiones (...).

Así, actualmente puede hablarse abiertamente de corrupción privada, concebida como una desviación fraudulenta o abusiva de potestades de control y decisión en la empresa privada que genera conflictos de intereses dentro del sector privado ${ }^{10}$ y que, de forma refleja o indirecta, puede afectar también al interés general.

Esto es, junto a la defraudación privada del sector público puede incluirse la defraudación del sector privado por el propio sector privado, personalizada normalmente en los cargos de administración y dirección de grandes empresas privadas con proyección pública, sea por su labor de intermediación en el sector financiero, o sea por su condición de sociedades anónimas cotizadas en mercados de valores, o por tratarse de sociedades de auditoría de cuentas que pueden ayudar o coadyuvar a falsificar ${ }^{11} \mathrm{u}$ ocultar el estado contable de empresas en crisis o en situaciones económicas delicadas antecedentes a una previsible crisis (así sucedió con la conexión de la empresa de auditoría Arthur Andersen en la crisis del caso

10 Sobre los conflictos de intereses como base de la corrupción en las empresas privadas, vid. ROSEACKERMAN, S. "Corruption an the Private Sector”, en HEIDENHEIMER, A.J./ JOHNSTON, M. / LEVINE, V.T. (Edits.), Political Corruption. A Handbook, cit., pp. 701 y ss.

11 Habitualmente la comisión de actos de corrupción en el sector privado requiere previamente la constitución de reservas ocultas (mediante contabilidades paralelas) que permite posteriormente la disposición de esos fondos negros o sucios en beneficio de los dirigentes o socios de control de la sociedad, desviándolos para operaciones ilícitas y/o poniéndolos a buen recaudo en cuentas secretas de paraísos fiscales. Vid. al respecto, DAVIGO, P. "Falso in bilancio, concussione e corruzione: l'esperienza giurisprudenziale", en MANNA, A. (a cura di), Falso in bilancio, concussione e corruzione: esperienze a confronto (Aspetti sostanziali e processuali), Acucci editore, Bari, 1998, pp. 21 y ss. 


\section{Enron) $)^{12}$}

Si la intervención pública en la economía, al asumir la iniciativa empresarial en sectores estratégicos e imponer fuertes barreras y controles para el acceso de la iniciativa privada a otros sectores, fue el caldo de cultivo ideal para la propagación de la corrupción en el sector público (al conjugarse intereses públicos y privados en mercados estratégicos por su trascendencia económica), los procesos de privatización de empresas públicas y la ola de liberalizaciones (desregulación) de mercados que viene produciéndose en las economías capitalistas desde el último cuarto del siglo $\mathrm{XX}$, han provocado un notable crecimiento de los escándalos financieros en la gran empresa privada con conexiones generalmente en los mercados financieros. La crisis financiera y económica desatada en los países desarrollados a partir de 2007 ha supuesto el culmen de este proceso, obligando a una intervención pública masiva para salvar empresas estratégicas, proteger a los ahorradores y subsidiar a los trabajadores en desempleo, y provocar una crisis de confianza en el sistema económico y financiero en su conjunto.

Las empresas públicas privatizadas y las grandes empresas privadas implantadas en sectores de gran interés para la Sociedad actual (sector energético, comunicaciones, transporte, sistema financiero y otros) han mostrado en muchas ocasiones la existencia de importantes conexiones con el poder político "desregulador", fraudes o irregularidades contables, situaciones continuadas de clientelismo (v.gr., relaciones plurales entre sociedades cotizadas y empresas auditoras que al tiempo realizan actividades de consultoría y asesoramiento para las mismas empresas que deben auditar ocultando graves defectos contables que han servido para crear situaciones aparentes de solvencia que no han hecho sino agravar la posición de los acreedores confiados en esa inexistente solvencia financiera y patrimonial), asimetrías informativas en los mercados de valores que fomentan el lucro de los centros de poder de las sociedades cotizadas frente al conjunto de los inversores mediante información privilegiada, o la perpetuación de los administradores y directores ("managers") en la cúpula de poder de las grandes empresas, a través de alianzas y de la consolidación progresiva de posiciones accionariales aprovechando, precisamente, las asimetrías informativas del mercado (v.gr., creciente recurso a amplios programas de "stock options" u opciones sobre acciones como remuneraciones en especie, o bien a programas de fondos de pensiones y seguros de vida cuyos activos se invierten en mercados de valores para garantizar remuneraciones y pensiones de jubilación desorbitadas) e interponiendo sus intereses personales sobre el interés social de la empresa que administran (gestionan y representan) y sobre los intereses privados (intereses de los accionistas o "shareholders" y de terceros o "stakeholders") y públicos implicados en el funcionamiento de los mercados en su conjunto.

12 Sobre el caso Enron y la implicación de la auditora Andersen, véase el artículo de BETANCOR, A. "Enron, liberalización, nueva economía", Política Exterior, No. 26, 2002, pp. 59 y ss. También, VALCÁRCEL, D., "Enron: una brecha abierta en el Sistema”, Política Exterior, No. 26, 2002. 
Estos conflictos de intereses en el sector privado ponen de manifiesto la fatal atracción y superioridad del poder y la ambición económica frente a los tradicionales -más aparentes que reales- criterios de honorabilidad en el campo profesional y laboral y frente a la ética de los negocios en general. Pues bien, para combatir estas situaciones se hace necesario algo más que el compromiso de honorabilidad, buen gobierno y responsabilidad social empresarial en el desarrollo de actividades económicas privadas; y algo más también que la abstracta definición de deberes de diligencia o deberes fiduciarios de gestores o que la voluntaria asunción de deberes de información y transparencia a través del "artificio" de los Códigos de Autorregulación, sean de práctica (de la empresa), de buen gobierno (de los cargos directivos) o de transparencia (en mercados financieros), propios de la etapa liberalizadora y de la nueva economía ("e-economía"). La experiencia ha demostrado el aumento progresivo de las prácticas abusivas y fraudulentas del poder empresarial y el mal funcionamiento de los mercados financieros en situaciones de ese tipo. También demuestra la experiencia la ineficacia de los llamados Códigos de Autorregulación o Códigos de Buen Gobierno y Transparencia por sí solos para frenar los graves escándalos financieros capaces de desequilibrar el regular funcionamiento del sistema financiero mundial.

La alarma social y la depauperada situación de las empresas y de los mercados reclaman medidas legales concretas y eficaces para frenar la corrupción en el sector privado. Es precisa la intervención del poder legislativo para establecer obligaciones específicas que favorezcan la gestión diligente y comprometida con el interés de la empresa, así como la transparencia y la información en sociedades cotizadas y en los mercados financieros, además de fuertes mecanismos de responsabilidad civil, administrativa y penal para los casos de incumplimiento. De ahí el nuevo movimiento de neo-regulación o re-regulación impulsado desde los mismos sectores políticos que impulsaron la liberalización.

No se trata de retornar a la época de la intervención pública masiva (como reclaman insistentemente algunas fuerzas políticas y corrientes de opinión) ni tampoco de desprivatizar las grandes empresas estratégicas. Se trata de encontrar el punto adecuado de equilibrio entre, por un lado, la necesaria eliminación de trabas a la iniciativa privada y a la libre competencia en cualesquiera sectores del mercado, y por otro lado, la creación de medidas eficaces de control que velen por el buen funcionamiento del mercado en términos de libre y leal competencia fomentando la transparencia y la información en la gestión de la empresa, en la actividad económica de producción y distribución y en la inversión en el sistema financiero. Todo ello acompañado de los pertinentes y estrictos mecanismos de responsabilidad y sanción para el caso -no poco frecuente- de incumplimiento; y también de la implantación y refuerzo de Autoridades o Agencias Públicas de Control que velen por el correcto funcionamiento de los mercados estratégicos (v.gr., Comisión Nacional del Mercado de Valores o Superintendencia Financiera, Banco Nacional, Comisión del Mercado de Energía Eléctrica, Dirección General de Seguros, Comisión del Mercado de 
Telecomunicaciones y otras) y del mercado en general en términos de competencia (cfr. Comisión de Defensa de la Competencia o Superintendencia de Comercio e Industria).

\section{Hacia una definición y control de la corrupción privada en convenciones regionales e internacionales}

Ante el avance imparable de la corrupción en el sector privado, además de concretas medidas legislativas nacionales (jurídico-privadas y administrativas) de carácter (neo-)regulador dirigidas a favorecer (restablecer) la diligencia, la transparencia y la responsabilidad en los mercados financieros y en la gestión de la empresa privada, la creciente importancia de la corrupción privada ha impulsado la elaboración de diversos instrumentos normativos internacionales o supranacionales en los que se fomenta precisamente la adopción de medidas de ese tipo por parte de los Estados firmantes para frenar comportamientos fraudulentos en la empresa privada y en los mercados.

Debe citarse aquí, en primer lugar, por su importancia en la primera definición del problema de la corrupción privada, la Acción Común 98/742/JAI del Consejo de Europa, de 22 de diciembre de 1998, sobre la corrupción en el sector privado, en la que, considerado que la corrupción falsea la competencia leal y compromete los principios de apertura y libertad de los mercados -en concreto, el correcto funcionamiento del mercado interior europeo-, además de ser contraria a la transparencia y a la apertura, crecimiento y consolidación del comercio internacional, se contempla y define la corrupción activa y pasiva en el sector privado, se propone su tipificación como infracción penal, al menos, cuando tales conductas supongan o puedan suponer una distorsión de la competencia, como mínimo en el marco del mercado común europeo, y causen o puedan causar perjuicios económicos a terceros debido a la adjudicación o a la ejecución irregular de un contrato.

En concreto, se entiende por corrupción pasiva en el sector privado (Art. 2),

"el acto intencionado de una persona que, directamente o por medio de terceros, solicite o reciba en el ejercicio de actividades empresariales ventajas indebidas de cualquier naturaleza, para sí misma o para un tercero, o acepte la promesa de tales ventajas, a cambio de realizar o abstenerse de realizar un acto incumpliendo sus obligaciones".

Y por corrupción activa en el sector privado (Art. 3),

"la acción intencionada de quien prometa, ofrezca o dé, directamente o por medio de terceros, una ventaja indebida de cualquier naturaleza a una persona para ésta o para un tercero, en el ejercicio de las actividades empresariales de dicha persona, para que ésta realice o se abstenga de realizar un acto incumpliendo sus obligaciones". 
También se prevé la imposición de sanciones a las personas jurídicas que puedan considerarse responsables de actos de corrupción activa o pasiva cometidos en su provecho por cualquier persona que las pueda representar. Sanciones que consistirán en multas de carácter penal o administrativo y que pueden incluir además otras medidas como la exclusión del disfrute de ventajas públicas, la prohibición temporal o permanente de desempeñar actividades comerciales, la vigilancia judicial e incluso su disolución ( $c f r$. Arts. 5 y 6$)^{13}$.

Puede advertirse en este instrumento normativo del Consejo de Europa que el bien jurídico protegido a raíz de la incriminación de conductas corruptas en el sector privado no es sólo la estructura patrimonial y el funcionamiento de las empresas afectadas (especialmente la relación de lealtad de los gestores con la empresa), sino fundamentalmente la estructura y correcto funcionamiento del mercado en términos de libre y leal competencia, con el objetivo último de la transparencia y de la apertura del comercio internacional ${ }^{14}$.

A estos fines se habla de corrupción privada en sentido estricto cuando los comportamientos fraudulentos afectan exclusivamente a los intereses particulares implicados en la empresa privada como consecuencia de la ruptura o infracción de deberes de diligencia, lealtad y secreto con los intereses de la empresa (el interés social en sociedades de capital). Y de corrupción privada en sentido amplio cuando las conductas fraudulentas en el sector privado conllevan un perjuicio superior, que excede los intereses de una concreta empresa privada, por afectar al desarrollo de la libre y leal competencia en el mercado y perjudica el desarrollo transparente y eficiente del mismo.

Sigue en esta misma línea de persecución de la corrupción en el sector privado a través de ilícitos penales, el no menos relevante Convenio del Consejo de Europa, de 27 de enero de 1999, de Derecho Penal sobre Corrupción (Cfr., Arts. 7, 8, 18 y $19)^{15}$; si bien parece que lo hace desde una perspectiva más restringida, pues pone el acento en la protección de las relaciones y de la estructura de las empresas afectadas por comportamientos abusivos y fraudulentos de sus administradores, directivos,

13 En este punto se plantea el complejo y debatido problema de la responsabilidad penal de las personas jurídicas (en el centro del debate se sitúa, una vez más, la conveniencia de mantener o abolir definitivamente el clásico principio de "societas delinquere non potest"), también de las medidas o consecuencias accesorias del delito (que a mi juicio, aunque desde la ignorancia del lego en Derecho penal, minimizan de alguna manera la discusión sobre la responsabilidad penal de la persona jurídica), y finalmente de la responsabilidad penal y civil de los administradores de hecho o de derecho de sociedades mercantiles, incluso en los casos en que los actos de corrupción hubieran beneficiado a la sociedad e indirectamente a todos sus accionistas, trabajadores, etc.

14 Vid. al respecto, FLORE, D. L'Incrimination de la Corruption (Lex nouveaux instruments internationaux. La nouvelle loi belge du 10 fèvrier 1999), La Charte, Bruxelles, 1999, pp. 13 y 39.

15 Ratificado por España con fecha de 26 de enero de 2010 
trabajadores e incluso colaboradores externos (agentes, auditores, y demás), y no tanto -a diferencia del instrumento anterior- en la defensa del mercado ${ }^{16}$.

En el Memorándum explicativo de este instrumento del Consejo de Europa sobre Derecho penal y corrupción se propone la inclusión de la corrupción privada como objeto de incriminación penal por la necesidad de coordinar las reglas aplicables en la lucha contra la corrupción en el sector público y privado, además de la conveniencia de asegurar el respeto a la competencia libre y leal; y todo ello a la vista de los procesos de privatización masiva de empresas públicas y de la ola de desregulación por la que se transfieren paulatinamente funciones públicas al sector privado.

El Convenio del Consejo de Europa, de 4 de noviembre de 1999, de Derecho Civil sobre Corrupción ${ }^{17}$ obliga a los Estados firmantes a establecer en sus ordenamientos internos procedimientos eficaces en favor de las personas que hayan sufrido daños resultantes de actos de corrupción, con el fin de permitirles defender sus derechos e intereses, incluida la posibilidad de obtener indemnizaciones por dichos daños (Art. 1). Estos remedios deben servir para paliar los daños y perjuicios sufridos tanto por actos de corrupción pública como de corrupción privada, incluidos los daños patrimoniales, el lucro cesante y los daños no patrimoniales (Art. 3.2).

Será necesario a tales fines que el demandado haya cometido o autorizado un acto de corrupción o que no haya tomado las medidas adecuadas para impedir un acto de corrupción, que el demandante haya sufrido un daño y que exista nexo de causalidad entre el acto de corrupción y el daño (Art. 4). Si se trata de actos de corrupción cometidos por agentes públicos, las reclamaciones de daños y perjuicios podrán dirigirse contra el Estado o contra otro tipo de Administración (Administración local) (Art. 5). Se tendrá en cuenta, además, posibles reducciones o supresiones de la indemnización por daños y perjuicios, con todas las circunstancias, en los casos en que el demandante haya contribuido, con su culpa, a que se produzca el daño o su agravación (Art. 6). Se establecen asimismo plazos de prescripción trianuales a partir de la fecha en que la persona que haya sufrido el daño hubiera tenido conocimiento o debiera haber tenido conocimiento del daño o del acto de corrupción y de la identidad de la persona o personas responsables; en ningún caso podrán admitirse demandas de daños y perjuicios una vez transcurridos diez años desde la comisión del acto de corrupción (Art. 7).

En cuanto a los contratos, se obliga a los Estados firmantes a declarar en su ordenamiento interno la nulidad de todo contrato o de toda cláusula contractual que tenga por objeto un acto de corrupción y deberán prever también la posibilidad de que las partes contratantes cuyo consentimiento esté viciado por un acto de corrupción puedan solicitar ante un tribunal la declaración de nulidad de dicho contrato, sin perjuicio de su derecho a la reclamación de daños (Art. 8).

16 Así, FLORE, L'Incrimination..., cit., pp. 67 y 68

17 Ratificado por España con fecha de 1 de diciembre de 2009 
Se prevé también que los Estados firmantes establezcan en su derecho interno medidas de protección adecuadas contra posibles sanciones injustificadas a los empleados que, teniendo motivos fundados de sospecha de actos de corrupción, hubieran denunciado de buena fe sus sospechas a las autoridades o personas responsables (Art. 9).

En materia contable, se dispone que cada Estado firmante adopte las medidas necesarias en su derecho interno para que las cuentas anuales de las empresas se establezcan con claridad y den una imagen fiel de la situación financiera de la empresa. A tales fines y para prevenir la comisión de actos de corrupción, cada Estado dispondrá en su derecho interno que los auditores comprueben que las cuentas anuales presentan una imagen fiel de la situación financiera de la empresa (Art. 10).

Finalmente se exige a los Estados firmantes establecer en su derecho interno procedimientos eficaces para la obtención de pruebas en el marco de los procedimientos civiles que tengan su origen en un acto de corrupción (Art. 11), así como las medidas cautelares judiciales que sean necesarias para garantizar los derechos y los intereses de las partes en el curso de los procedimientos civiles que tengan su origen en un acto de corrupción (Art. 12).

En 2003 la Unión Europea aprobó e hizo pública la Decisión Marco 2003/568/ JAI del Consejo, de 22 de julio de 2003, relativa a la lucha contra la corrupción en el sector privado, que deroga la antes mencionada Acción Común 98/742/JAI del Consejo de Europa, de 22 de diciembre de 1998, sobre la corrupción en el sector privado. En esta Decisión Marco se reconoce que la corrupción en el sector privado se ha convertido en un problema transnacional que requiere, para combatirlo en el ámbito europeo, una acción conjunta de la Unión Europea. Según el Preámbulo de esta Decisión Marco, los Estados miembros de la Unión Europea conceden una importancia especial a la lucha contra la corrupción tanto en el sector público como en el privado, por estimar que en ambos sectores constituye una amenaza para el Estado de Derecho, al tiempo que distorsiona la competencia respecto de la adquisición de bienes o servicios comerciales e impide un desarrollo económico sólido, por ello, se fija como objetivos de la Decisión Marco asegurar que la corrupción activa y pasiva en el sector privado sea una infracción penal en todos los Estados miembros, incluidas la complicidad y la incitación (cfr., Arts. 2-4), y que las personas jurídicas también puedan ser consideradas responsables de tales delitos y que éstos se castiguen con sanciones efectivas, proporcionadas y disuasorias (cfr., Arts. 5-6).

Como luego veremos, esta Decisión Marco 2003/568/JAI del Consejo de la Unión Europea, constituye el paso definitivo para la tipificación como delito de la corrupción en el sector privado y también para la definitiva abolición del principio "societas delinquere non potest" y la consiguiente imputación criminal de las personas jurídicas en la Unión Europea.

Más allá de los instrumentos normativos europeos sobre la corrupción, reviste una importancia trascendental en esta materia la Convención de Naciones Unidas contra la Corrupción, aprobada por la Resolución No. 58/4 de la Asamblea General de Naciones Unidas, con fecha 31 de octubre de 2003 y en vigor desde 2005, que 
constituye el primer instrumento global para prevenir y luchar contra la corrupción basado en un amplio consenso internacional.

Esta Convención de Naciones Unidas parte de una concepción amplia y multidisciplinar del fenómeno de la corrupción, teniendo muy presente que las consecuencias de la corrupción afectan no sólo al sector público sino también, y de manera muy importante, al sector privado, obstaculizando sobremanera las transacciones comerciales, tecnológicas y financieras en el tráfico económico internacional $^{18}$.

Así, los Estados firmantes de esta Convención convencidos que la corrupción ha dejado de ser un problema local para convertirse en un fenómeno transnacional que afecta a todas las sociedades y economías, lo que hace esencial la cooperación internacional para prevenirla y luchar contra ella; convencidos también de que se requiere un enfoque amplio y multidisciplinario para prevenir y combatir eficazmente la corrupción y de que el enriquecimiento personal ilícito puede ser particularmente nocivo para las instituciones democráticas, las economías nacionales y el imperio de la ley. Decididos a prevenir, detectar y disuadir con mayor eficacia las transferencias internacionales de activos adquiridos ilícitamente y a fortalecer la cooperación internacional para la recuperación de activos; reconocidos los principios fundamentales del debido proceso en los procesos penales y en los procedimientos civiles o administrativos sobre derechos de propiedad; teniendo presente que la prevención y la erradicación de la corrupción son responsabilidades de todos los Estados y que éstos deben cooperar entre sí, con el apoyo y la participación de personas y grupos que no pertenecen al sector público, como la sociedad civil, las organizaciones no gubernamentales y las organizaciones de base comunitaria, para que sus esfuerzos en este ámbito sean eficaces; y teniendo presente también los principios de debida gestión de los asuntos y los bienes públicos, equidad, responsabilidad e igualdad ante la ley, así como la necesidad de salvaguardar la integridad y fomentar una cultura de rechazo de la corrupción; en línea con otros instrumentos de diversas organizaciones internacionales en la lucha contra la corrupción establece una serie de medidas para prevenir y combatir la corrupción en sus distintas manifestaciones.

En particular el artículo 12 aborda la corrupción en el sector privado, al señalar que:

"Cada Estado parte, de conformidad con los principios fundamentales de su derecho interno, adoptará medidas para prevenir la corrupción y mejorar las normas contables y de auditoría en el sector privado, así como, cuando proceda, prever sanciones civiles, administrativas o penales eficaces, proporcionadas y disuasivas en caso de incumplimiento de esas medidas" (Art. 12.1).

18 Vid. ARGANDOÑA, A., La Convención de las Naciones Unidas sobre la Corrupción y su impacto sobre las empresas internacionales, accesible en el sitio http://www.eben-spain.org/docs/Papeles/ XIV/ARGANDOnA_ANTONIO.pdf. 
Las medidas que se adopten para alcanzar esos fines podrán consistir, entre otras cosas, en (Art. 12.2): a) promover la cooperación entre los organismos encargados de hacer cumplir la ley y las entidades privadas pertinentes; b) promover la formulación de normas y procedimientos encaminados a salvaguardar la integridad de las entidades privadas pertinentes, incluidos códigos de conducta para el correcto, honorable y debido ejercicio de las actividades comerciales y de todas las profesiones pertinentes y para la prevención de conflictos de intereses, así como para la promoción del uso de buenas prácticas comerciales entre las empresas y en las relaciones contractuales de las empresas con el Estado; c) promover la transparencia entre entidades privadas, incluidas, cuando proceda, medidas relativas a la identidad de las personas jurídicas y naturales involucradas en el establecimiento y la gestión de empresas; d) prevenir la utilización indebida de los procedimientos que regulan a las entidades privadas, incluidos los procedimientos relativos a la concesión de subsidios y licencias por las autoridades públicas para actividades comerciales; $e$ ) prevenir los conflictos de intereses e imponer restricciones apropiadas, durante un período razonable, a las actividades profesionales de ex funcionarios públicos o a la contratación de funcionarios públicos en el sector privado tras su renuncia o jubilación cuando esas actividades o esa contratación estén directamente relacionadas con las funciones desempeñadas o supervisadas por esos funcionarios públicos durante su permanencia en el cargo; $f$ ) velar porque las empresas privadas, según su estructura y tamaño, dispongan de suficientes controles contables internos para ayudar a prevenir y detectar los actos de corrupción, y porque las cuentas y los estados financieros requeridos de esas empresas privadas estén sujetos a procedimientos apropiados de auditoría y certificación.

Indica asimismo que (Art. 12.3), a fin de prevenir la corrupción, cada Estado parte adoptará las medidas que sean necesarias, de conformidad con sus leyes y reglamentos internos relativos al mantenimiento de libros y registros, la divulgación de estados financieros y las normas de contabilidad y auditoría, para prohibir los siguientes actos realizados con el fin de cometer cualesquiera de los delitos tipificados con arreglo a la presente Convención: a) el establecimiento de cuentas no registradas en libros; b) la realización de operaciones no registradas en libros o mal consignadas; $c$ ) el registro de gastos inexistentes; $d$ ) el asiento de gastos en los libros de contabilidad con indicación incorrecta de su objeto; e) la utilización de documentos falsos; y f) La destrucción deliberada de documentos de contabilidad antes del plazo previsto en la ley.

Finalmente, dispone que cada Estado parte denegará a las empresas la deducción tributaria respecto de gastos que constituyan soborno de funcionarios públicos nacionales o de funcionarios públicos extranjeros y de funcionarios de organizaciones internacionales públicas $\mathrm{y}$, cuando proceda, respecto de otros gastos que hayan tenido por objeto promover un comportamiento corrupto (Art. 12.2).

En definitiva, podrá observarse cómo la Convención de Naciones Unidas impone a los Estados firmantes obligaciones en materia de prevención y represión 
de la corrupción, insiste en particular en la necesidad de impulsar la transparencia contable y la auditoría de cuentas, así como los códigos de buen gobierno corporativo para la prevención de conflictos de intereses para fortalecer la honorabilidad y la transparencia en la gestión de las entidades privadas, presta también especial atención a la prevención y la transparencia en las relaciones de las empresas con la Administración pública en materia de contratación, así como a la contratación de antiguos funcionarios públicos en el sector privado cuando la actividad para la que se le contrata esté directamente relacionada con las funciones que desempeñaba anteriormente en el sector público.

En concreto, para prevenir la corrupción en las entidades privadas se conmina a los Estados firmantes para que extremen las precauciones en materia contable, exijan llevar libros de contabilidad y el registro y divulgación de estados patrimoniales y financieros, así como la tipificación de delitos contables relacionados con el falseamiento y destrucción de la contabilidad (cfr., Art. 12.3).

También con carácter específico, el Art. 21 de la Convención se ocupa del soborno en el sector privado, al disponer que cada Estado parte considerará la posibilidad de adoptar las medidas legislativas y de otra índole que sean necesarias para tipificar como delito, cuando se cometan intencionalmente en el curso de actividades económicas, financieras o comerciales: a) la promesa, el ofrecimiento o la concesión, en forma directa o indirecta, a una persona que dirija una entidad del sector privado o cumpla cualquier función en ella, de un beneficio indebido que redunde en su propio provecho o en el de otra persona, con el fin que, al faltar el deber inherente a sus funciones, actúe o se abstenga de actuar (corrupción activa en el sector privado); b) la solicitud o aceptación, en forma directa o indirecta, por una persona que dirija una entidad del sector privado o cumpla cualquier función en ella, de un beneficio indebido que redunde en su propio provecho o en el de otra persona, con el fin que, faltando al deber inherente a sus funciones, actúe o se abstenga de actuar (corrupción pasiva en el sector privado).

El Art. 22 de la Convención establece que cada Estado firmante considerará la posibilidad de adoptar las medidas legislativas y de otra índole que sean necesarias para tipificar como delito, cuando se cometan intencionalmente en el curso de actividades económicas, financieras o comerciales, la malversación o el peculado, por una persona que dirija una entidad del sector privado o cumpla cualquier función en ella, de cualesquiera bienes, fondos o títulos privados o de cualquier otra cosa de valor que se hayan confiado a esa persona por razón de su cargo.

Por lo demás, conviene destacar que el Art. 26 conmina a los Estados parte de la Convención a adoptar las medidas necesarias para establecer la responsabilidad de personas jurídicas por su participación en delitos tipificados de corrupción, con arreglo a lo dispuesto en la misma Convención. Aunque pareciere que la Convención exige tipificar la responsabilidad penal de las personas jurídicas y terminar así con el clásico principio "societas delinquere non potest", sin embargo, con la intención de respetar los principios jurídicos de cada Estado parte, señala expresamente 
que la responsabilidad de las personas jurídicas podrá ser de índole penal, civil o administrativa, y que existirá sin perjuicio de la responsabilidad que incumba a las personas naturales que hayan cometido delitos, obliga en todo caso a los Estados firmantes a que impongan sanciones penales o no penales eficaces, proporcionadas y disuasorias, incluidas sanciones monetarias a las personas jurídicas consideradas responsables de ilícitos penales.

El Art. 34 se ocupa de las consecuencias de los actos de corrupción, dispone que, con la debida consideración de los derechos adquiridos de buena fe por terceros, cada Estado parte, de conformidad con los principios fundamentales de su derecho interno, adoptará medidas para eliminar las consecuencias de los actos de corrupción, señala en particular la posibilidad de crear procedimientos jurídicos encaminados a anular o dejar sin efecto un contrato o revocar una concesión u otro instrumento semejante o adoptar cualquier otra medida correctiva. En esa misma línea, el Art. 35 establece que cada Estado parte adoptará las medidas que sean necesarias, de conformidad con los principios de su derecho interno, para garantizar que las entidades o personas perjudicadas como consecuencia de un acto de corrupción tengan derecho a iniciar una acción legal contra los responsables de esos daños y perjuicios a fin de obtener indemnización. De tal suerte, la Convención de Naciones Unidas sobre Corrupción se alinea con los objetivos y principios normativos básicos establecidos en los Convenios del Consejo de Europa de Derecho Penal y de Derecho Civil sobre Corrupción, de 27 de enero y 4 de noviembre de 1999 respectivamente.

Asimismo, la Convención de Naciones Unidas establece una serie de obligaciones específicas a los Estados parte de la misma para poder llevar a cabo una lucha eficaz contra actos de corrupción, tanto en el sector público como en el sector privado. Entre ellas destacan la creación de Autoridades específicas especializadas en la lucha contra la corrupción (Art. 36), el impulso de la cooperación de quienes hayan participado en la comisión de actos de corrupción (a cambio de mitigar la pena e incluso atribuir inmunidad judicial; Art. 37), la promoción de la cooperación entre organismos nacionales en la lucha contra la corrupción (Art. 38) y de la cooperación entre organismos nacionales de lucha contra la corrupción (como organismos nacionales de investigación y el Ministerio Fiscal) y entidades del sector privado (especialmente instituciones financieras), alienta incluso la denuncia o delación de actos de comisión ante las Autoridades competentes (Art. 39) y vela porque, en el caso de investigaciones penales nacionales de delitos tipificados de corrupción, existan en el ordenamiento interno mecanismos apropiados para salvar todo obstáculo que pueda surgir como consecuencia de la aplicación de la legislación relativa al secreto bancario (Art. 40).

Finalmente, a partir del carácter cada vez más global o trasnacional de los actos de corrupción, la Convención dedica el Capítulo IV (Arts. 43-50) a la cooperación judicial internacional en la lucha contra la corrupción, el Capítulo V (Arts. 5159) a la recuperación de activos, que se considera un principio fundamental de la Convención, por lo que se hace un llamamiento a los Estados parte para prestarse 
la más amplia cooperación y asistencia entre sí a este respecto, establece medidas civiles y administrativas de prevención y detección de transferencias del producto de delitos de corrupción (las cuales afectan fundamentalmente a las instituciones financieras), medidas para la recuperación directa de bienes (decomiso) y medidas para la restitución de activos a sus legítimos propietarios.

En el ámbito de la lucha contra la corrupción en la empresa privada se sitúan también las Líneas Directrices de la OCDE para Empresas Multinacionales, del año 2000, que son recomendaciones dirigidas por los Gobiernos que forman parte de dicha organización a las empresas multinacionales para promover una conducta empresarial responsable. Como tales recomendaciones su cumplimiento es voluntario pero se anima a su cumplimiento a las empresas multinacionales y también a las nacionales.

El Capítulo VI de estas Directrices establece Recomendaciones para la Lucha contra la Corrupción en las empresas multinacionales, enuncia como principio general que las empresas no deberán ofrecer, prometer, dar ni solicitar, directa o indirectamente, pagos ilícitos u otras ventajas indebidas para obtener o conservar un contrato u otra ventaja ilegítima, como tampoco se deberá solicitar a las empresas que ofrezcan, ni esperar que lo hagan, pagos ilícitos u otras ventajas indebidas.

Se disponen como recomendaciones concretas a las empresas: que no deberán ofrecerse a pagar ni ceder ante las peticiones de pago a funcionarios o a empleados de socios empresariales ninguna fracción de un pago contractual; que no deberán utilizar subcontratistas, órdenes de compra ni contratos de consultoría como medio para canalizar pagos a funcionarios, empleados de socios empresariales o a sus familiares o socios comerciales; que deberán velar por que la retribución de los representantes sea adecuada y corresponda exclusivamente a servicios legítimos, y que, cuando corresponda, deberá conservarse y ponerse a disposición de las autoridades competentes una lista de los representantes empleados en relación con operaciones con organismos públicos y empresas públicas; que deberán mejorar la transparencia de sus actividades de lucha contra la corrupción y la extorsión, incluyen la asunción de compromisos públicos contra la corrupción y la extorsión, así como la divulgación de los sistemas de gestión adoptados por la empresa para cumplir con sus compromisos; que deberán fomentar el conocimiento y respeto por parte de los trabajadores de las políticas de la empresa contra la corrupción y la extorsión a través de una difusión adecuada de estas políticas y mediante programas de formación y procedimientos disciplinarios; que deberán introducir sistemas de control de gestión que desincentiven la corrupción y las prácticas corruptas y corruptoras y adoptar prácticas de contabilidad general y fiscal y de auditoría que eviten la existencia de dobles contabilidades o de cuentas secretas o la creación de documentos en los que no queden anotadas, de manera correcta y justa, las operaciones a las que corresponden; y que no deberán realizar contribuciones ilícitas a candidatos a cargos públicos ni a partidos políticos u otras organizaciones políticas. 
Finalmente es preciso incluir el Pacto Mundial de Naciones Unidas, signado el 26 de julio de 2000, cuyo fin es impulsar la responsabilidad empresarial para que todos los pueblos del mundo compartan los beneficios de la globalización e inyectar en el mercado mundial los valores y prácticas fundamentales para resolver las necesidades económicas. Este Pacto se plasma en diez principios que recogen valores fundamentales que se pretenden trasladar a las empresas privadas sobre derechos humanos, normas laborales, medio ambiente y lucha contra la corrupción. En concreto el décimo principio sobre lucha contra la corrupción se incluyó en el año 2004 tras la aprobación de la Convención de Naciones Unidas contra la Corrupción. Según este principio las empresas deben trabajar contra la corrupción en todas sus formas, incluidos la extorsión y el soborno.

$* * *$

De los convenios internacionales analizados se desprende con meridiana claridad que, a pesar del creciente protagonismo que ha adquirido la corrupción en el sector privado, la acción de los organismos internacionales en la lucha contra la corrupción está orientada a combatir por igual los comportamientos corruptos en el sector público y en el sector privado, ya que en la práctica frecuentemente coinciden corrupción en el sector público y corrupción en el sector privado. Como ha señalado algún autor, “corrupción pública y corrupción privada son dos caras de una misma moneda"19.

Efectivamente, la corrupción en el sector privado tiene en muchas ocasiones origen y/o reflejo en el sector público: sea por la existencia de conexiones ilícitas con cargos políticos o con funcionarios y agentes de la Administración Pública que facilitan la adjudicación de contratos de compraventa de bienes o prestación de servicios con preferencia a los competidores, así como con cargos directivos y el personal de las autoridades o agencias de control de los mercados financieros, o sea porque los perjuicios que la corrupción privada genera en grupos de intereses privados acaba por afectar también al propio interés público en el funcionamiento eficiente de esos mercados y en la confianza misma en el sistema económico en su conjunto.

Esta conexión entre las dos manifestaciones de la corrupción se hace más palpable aún ante el proceso de globalización de la economía que caracteriza la moderna Sociedad transmilenaria ${ }^{20}$. La globalización de los mercados potencia, sin duda, las posibilidades de comportamientos corruptos, ante el afán de las empresas poderosas

19 GARCÍA MEXÍA, Los conflictos..., cit., p. 49.

20 Sobre la globalización y su incidencia sobre la sociedad y la economía mundial y el derecho pueden consultarse, entre otras muchas, las siguientes obras: DE LA DEHESA, G., Comprender la Globalización, Alianza Editorial, Madrid, 2000; BLANCH A. (Ed.), Luces y Sombras de la Globalización, Publicaciones de la Universidad Pontificia de Comillas ICADE, Madrid, 2000; AA.VV., Transformaciones del Derecho en la Mundialización, Estudios de Derecho Judicial, 16, 2000; GARCÍA-CRUCES GONZÁLEZ, J.A., Globalización Económica y Derecho Mercantil, Publicaciones de la Facultad de Derecho de la Universidad de Zaragoza, 2002. 
por situarse en condiciones favorables en países desarrollados y en vías de desarrollo (aprovechando en muchas ocasiones los déficit de organización democrática de estos últimos) para obtener así posiciones de ventaja en el comercio internacional21, para lo cual no dudarán en sobornar a funcionarios públicos extranjeros (y también a funcionarios de Organizaciones Internacionales) que les faciliten el establecimiento o la entrada de sus productos o servicios en terceros países ${ }^{22}$.

La globalización (gracias a los avances en las técnicas de comunicación, tomado como paradigma su máxima expresión: Internet) también facilita extraordinariamente la circulación de capitales ilícitos por los mercados financieros de todo el mundo y su "ocultación" (a buen recaudo) en cualquiera de los muchos paraísos fiscales, financieros e informáticos que proliferan últimamente en diferentes partes del planeta. Destaca a estos efectos el fenómeno del "forum shopping", por el cual los países entran en competencia directa en la lucha por atraer capitales a sus respectivos mercados mediante legislaciones favorables que eliminan trabas a la iniciativa empresarial y a la inversión. Manifestación que resulta particularmente nociva para el orden económico mundial en el caso de los paraísos fiscales donde la total eliminación de trabas para la inversión de capitales extranjeros y la ausencia de políticas fiscales se acompaña de una total opacidad en el sistema financiero y falta de colaboración con terceros países, lo cual constituye un ingrediente esencial

21 Vid. KIMBERLY, A.E., (Edit.), Corruption and the Global Economy, Institute for International Economics", Washington DC, 1997. Vid. también MALEM SEÑA, J.F., Globalización, comercio internacional y corrupción, Gedisa, Barcelona, 2000. En la empresa privada podemos encontrarnos con decisiones de los altos cargos directivos al margen de la voluntad común de los accionistas orientadas a la desviación de importantes sumas de dinero en concepto de comisiones ilegales para hacerse con el control de sociedades de terceros países estratégicamente situadas en un sector concreto del mercado y, a la inversa, con oscuras decisiones de venta de activos de la empresa o sociedades filiales del grupo a precios reducidos a competidores de terceros países que quieren entrar en el mercado nacional cobrando a cambio jugosas comisiones por la adopción de estas decisiones arbitrarias a espaldas de los accionistas como propietarios indirectos de la empresa. También la globalización afecta a los sistemas financieros, con la inestimable ayuda de las nuevas tecnologías, permitiendo la circulación de capitales y la inversión a lo largo y ancho del mundo (con destino final o intermedio en paraísos financieros e informáticos), factor que favorece las posibilidades de circulación y reciclaje de la riqueza ilícita proveniente del sector público y la desviación de fondos fruto de abusos de poder dentro de la empresa privada.

22 Para combatir la corrupción de funcionarios extranjeros se han adoptado diferentes instrumentos de carácter internacional con la intención de que los Estados incluyan en su legislación interna las medidas referidas en los mismos. Entre otros destacan la Declaración de Naciones Unidas, de 21 de febrero de 1997, sobre la corrupción y los sobornos en las transacciones comerciales internacionales; la Acción de Naciones Unidas, de 15 de diciembre de 1998, sobre la corrupción y los sobornos en las transacciones comerciales internacionales; y el Convenio de la OCDE, de 17 de diciembre de 1997, de lucha contra la corrupción de agentes públicos extranjeros en las transacciones comerciales internacionales, que motivó en España la promulgación de la Ley Orgánica 3/2000, de 11 de enero de modificación de la Ley Orgánica 10/1995, de 23 de noviembre, del Código Penal, para crear un nuevo Título XIX bis, compuesto por los Arts. 4445 y 445 bis CP en el que se tipifican los delitos de corrupción en las transacciones comerciales internacionales. 
para incentivar más la corrupción pública y privada y un gravísimo obstáculo en la lucha contra la misma, ante la sistemática falta de colaboración de las autoridades de estos países netamente favorecidos en su economía nacional por la fuga de capitales (lícitos o ilícitos) de terceros países ${ }^{23}$.

Finalmente, las connivencias y conciliábulos entre los administradores de grandes empresas multinacionales y sociedades de auditores de cuentas, pueden servir para emitir informes falseados que oculten o maquillen la situación patrimonial y financiera de una empresa, creando una apariencia de solvencia que no existe en la realidad y determine así el comportamiento de los inversores y de los acreedores. Realmente estas connivencias entre los administradores de la empresa y de los auditores (expertos teóricamente independientes) puede llegar a afectar a distintos grupos de intereses convergentes en la empresa y al sistema económico en su conjunto, pues el maquillaje contable no hace, por lo general, sino aplazar la insolvencia de la empresa, al generar una apariencia de normalidad que luego -cuando se produzca la insolvencia y la interrupción de la actividad- puede perjudicar gravemente a socios inversores, trabajadores, acreedores e incluso a los consumidores, afecta también el funcionamiento normal del mercado financiero y de valores, a las compañías de seguros $\mathrm{y}$, en definitiva, al funcionamiento eficiente del sistema económico en su conjunto.

Llegados a este punto podemos aportar una definición amplia y abierta de corrupción como toda conducta desviada, fraudulenta y desleal en la gestión de intereses públicos o privados que persigue en todo caso la obtención de un beneficio privado (egoísta), generalmente económico, para el sujeto que comete el acto ilícito o para un tercero, en detrimento del interés público y de intereses privados particulares y colectivos. La interposición de un interés privado de naturaleza económica genera un auténtico "mercado de la corrupción", tanto en el sector público como en el sector privado que da lugar así a una "economía de la transgresión" 24.

Por eso, este trabajo no se limita a analizar la corrupción en el sector privado en sentido estricto, esto es, las operaciones de corrupción activa y pasiva entre empresas o entidades privadas (sociedades, asociaciones, fundaciones y otras), sino que incluye también los actos de corrupción entre empresas y entidades privadas y autoridades, funcionarios o empleados de las Administraciones pública, al estar el origen de la corrupción en el sector privado.

23 De hecho muchos intermediarios financieros de los países más desarrollados establecen habitualmente filiales en estos países con legislaciones más favorables para la inversión con la finalidad de enfocar hacia ellos parte de su propia operativa (operaciones financieras, desvío de fondos) y la de sus clientes preferenciales. Todo ello, por supuesto, al margen de las autoridades de control de los distintos mercados financieros del país de procedencia.

24 Vid. la obra de MAGADÁN DÍAZ, M. y RIVAS GARCÍA, J., Corrupción y fraude: economía de la transgresión, Madrid, 1999. 


\section{La interrelación entre corrupción y derecho. En particular, corrupción y derecho privado patrimonial}

\section{Corrupción y Derecho público sancionador. En particular, el delito de corrupción entre particulares y el reconocimiento de la responsabilidad penal de las personas jurídicas}

Aunque el problema de la corrupción tiene una dimensión principalmente sociológica y política, conocida la estrecha y necesaria relación entre Derecho y Sociedad, la corrupción puede y debe ser abordada desde el terreno de la ciencia jurídica en cuanto ciencia comprensiva y solutoria de los problemas sociales planteados en cada momento histórico.

Desde la perspectiva jurídica, puede decirse que el fenómeno de la corrupción se ha limitado tradicionalmente en términos político-jurídicos al ámbito iuspublicista; en concreto, los comportamientos corruptos o fraudulentos han sido y son objeto de atención fundamentalmente por el Derecho penal y administrativo ( $c f r$. delitos contra la administración pública, societarios y contra el mercado, régimen de incompatibilidades de los funcionarios públicos, responsabilidad patrimonial de la administración, derecho administrativo sancionador (...).).

El carácter sancionador o represivo del Derecho administrativo sancionador y, sobre todo, la amenaza que constituye siempre el Derecho penal, actúan como factor preventivo fundamental de los actos de corrupción. Este doble factor preventivo-represivo resulta fundamental en la lucha contra la corrupción en el sector privado impulsada desde la Unión Europea, Naciones Unidas y otras instancias internacionales.

De hecho, tras la aprobación de los Convenios regionales e internacionales antes mencionados, en especial la Convención de Naciones Unidas contra la Corrupción, la corrupción privada ha sido incluida como nuevo tipo delictivo en los Códigos Penales de muchos de los países firmantes, entre ellos los Estados miembros de la Unión Europea tras el impulso que supuso la ya comentada Decisión Marco 2003/568/JAI del Consejo, de 22 de julio de 2003.

En España, la Ley Orgánica 5/2010, de 22 de junio, de reforma del Código Penal, ha introducido el delito de corrupción entre particulares (cfr., Sección 4a , del Capítulo XI del Título XIII del Libro II, Art. 286bis CP). Según la Exposición de Motivos de la citada Ley (apartado XIX), la idea fundamental en este ámbito es que la garantía de una competencia justa y honesta pasa por la represión de los actos encaminados a corromper a los administradores de entidades privadas de forma similar a lo que ya se hace a través del delito de cohecho para los agentes públicos, ya que en estos comportamientos, que -señala- exceden la esfera de lo privado, se rompen las reglas de buen funcionamiento del mercado, siendo relevante la importancia del problema si se repara en la repercusión que pueden tener las decisiones empresariales, no sólo 
para sus protagonistas inmediatos, sino para otras muchas personas.

Así, el Art. 286bis del nuevo Código Penal español dispone que quien por sí o por persona interpuesta prometa, ofrezca o conceda a directivos, administradores, empleados o colaboradores de una empresa mercantil o de una sociedad, asociación, fundación $\mathrm{u}$ organización un beneficio o ventaja de cualquier naturaleza no justificados para que le favorezca a él o a un tercero frente a otros o incumpla sus obligaciones en la adquisición o venta de mercancías o en la contratación de servicios profesionales, será castigado con la pena de prisión de seis meses a cuatro años, inhabilitación especial para el ejercicio de industria o comercio por tiempo de uno a seis años y multa del tanto al triplo del valor del beneficio o ventaja; castigándose con las mismas penas al directivo, administrador, empleado o colaborador de una empresa mercantil, o de una sociedad, asociación, fundación u organización que, por sí o por persona interpuesta, reciba, solicite o acepte un beneficio o ventaja de cualquier naturaleza no justificados con el fin de favorecer frente a terceros a quien le otorga o del que espera el beneficio o ventaja, incumpliendo sus obligaciones en la adquisición o venta de mercancías o en la contratación de servicios profesionales ${ }^{25}$.

De tal modo se criminaliza la corrupción activa y pasiva en el sector privado en sentido amplio, incluido también el llamado tercer sector (fundaciones, asociaciones o cualesquiera otras organizaciones no gubernamentales ni estrictamente empresariales) y el campo del deporte profesional. Y se hace -como dice la Exposición de Motivos- sobre la base del impacto negativo que comportamientos corruptos en el sector privado tienen sobre la libre y leal competencia en el mercado, hasta el punto de poder alterar las reglas de buen funcionamiento del mismo basadas en el concepto de competencia por eficiencia (que cada operador actúe en el mercado con sus propios medios sin obstaculizar ni aprovecharse de la posición competitiva de terceros), y que son susceptibles de afectar a todos los grupos de intereses concurrentes en el mercado, esto es, los intereses de competidores, de trabajadores, de acreedores, de consumidores, de inversores e incluso el propio interés general en el correcto funcionamiento del mercado.

Esta conexión entre la corrupción privada y el mercado revela que tras los comportamientos corruptos, consistentes en el ofrecimiento y solicitud o aceptación de sobornos en forma de beneficios o ventajas de cualquier naturaleza no justificados por los directivos, administradores, empleados o colaboradores de una empresa mercantil o de una sociedad, asociación, fundación u organización para favorecer

25 El apartado 4 del Art. 286bis CP dispone que las penas dispuestas en el mismo serán aplicables también, en sus respectivos casos, a los directivos, administradores, empleados o colaboradores de una entidad deportiva, cualquiera que sea la forma jurídica de ésta, así como a los deportistas, árbitros o jueces, respecto de aquellas conductas que tengan por finalidad predeterminar o alterar de manera deliberada y fraudulenta el resultado de una prueba, encuentro o competición deportiva profesionales, abordando así el problema de la corrupción activa y pasiva en las competiciones deportivas. 
a quien ofrece el soborno o a un tercero en detrimento de otros, incumplidas sus obligaciones en la adquisición o venta de mercancías o en la contratación de servicios profesionales, están muy presentes los comportamientos desleales en el mercado, entendidos como aquellos que resulten objetivamente contrarios a las exigencias de la buena $\mathrm{fe}^{26}$. Es claro, en este sentido, que los actos de corrupción activa y pasiva en el sector privado constituyen actos realizados en el mercado con fines concurrenciales, ya que pueden entenderse como actos idóneos para promover o asegurar la difusión en el mercado de las prestaciones propias o de un tercero (el sujeto que ofrece el soborno o un tercero $)^{27}$, y también que los actos de competencia desleal pueden ser cometidos por empresarios y profesionales y también por cualesquiera otras personas físicas o jurídicas que participan en el mercado con fines concurrenciales propios o de terceros, sin que sea imprescindible la existencia de una relación de competencia entre el sujeto activo y el sujeto pasivo del acto de competencia desleal ${ }^{28}$ pudiendo, por tanto, incluir dentro de los sujetos activos y pasivos de actos concurrenciales a los directivos, administradores, empleados o colaboradores de una empresa mercantil o de una sociedad, asociación, fundación u organización, esto es, tanto a los empresarios individuales y profesionales liberales como a los administradores, directivos, colaboradores y empleados de empresarios personas jurídicas, sean sociedades mercantiles, fundaciones o asociaciones, pues se trata de personas físicas que actúan en el mercado en representación de personas jurídicas y que, por tanto, pueden tomar decisiones que afecten al comportamiento de mercado de su propia empresa y de terceros. Expresado de otro modo: los administradores, directivos, colaboradores y empleados de empresarios individuales (personas físicas o naturales) y de empresarios sociales, fundaciones, asociaciones y otras organizaciones, no sólo tienen obligaciones de diligencia y lealtad con su empresario o principal en el cumplimiento de sus obligaciones legales y contractuales, sino también deberes legales de comportamiento correcto o leal en el mercado y, por tanto, frente a todos aquellos que operan o tienen intereses en el mismo, sean competidores, inversores o consumidores; en particular tienen el deber legal de no obstaculizar la posición competitiva de terceros, lo que incluye el deber de no favorecer a unos operadores en beneficio de otros. En consecuencia, sobornar o dejarse sobornar por un tercero para firmar o no firmar un determinado contrato, puede conllevar un perjuicio para los competidores, que no podrán contratar en igualdad de condiciones y, también, de forma refleja o indirecta, ese comportamiento puede afectar a los consumidores e incluso al funcionamiento eficiente del mercado. Se explica así la inclusión del nuevo delito de corrupción entre particulares entre los delitos relativos a la propiedad

26 Tal y como son definidos en la cláusula general de competencia desleal recogida en el Art. 4.1 de la Ley 3/1991, de 10 de enero de competencia desleal española (LCD) y, de manera similar, en el Art. 7 de la Ley 256 de 1996 de la República de Colombia, donde se habla de actos o hechos contrarios a las sanas costumbres mercantiles o al principio de buena fe comercial.

27 Cfr., Art. 2 LCD española y Art. 2 de la Ley 256 de 1996 colombiana.

28 Cfr., Art. 3 LCD española y Art. 3 de la Ley 256 de 1996 colombiana. 
industrial e intelectual, al mercado y a los consumidores (Capítulo XI, Título XIII, Libro II).

Junto a la tipificación del delito de corrupción privada y de acuerdo con lo dispuesto en los Convenios internacionales antes mencionados y con lo expresamente previsto en la Decisión Marco 2003/568/JAI del Consejo, de 22 de julio de 2003, la Ley Orgánica 5/2010 de reforma del Código Penal español ha establecido por primera vez la responsabilidad penal de las personas jurídicas, la cual, no obstante, se reserva para aquellas figuras delictivas donde la posible intervención de las personas jurídicas se hace más evidente, entre las que cuentan, precisamente, la corrupción en el sector privado o las transacciones comerciales internacionales29. Se aclara, asimismo, que la responsabilidad penal de la persona jurídica podrá declararse con independencia de que se pueda individualizar o no la responsabilidad penal de la persona física que actúe como administrador de hecho o derecho de la misma o como representante voluntario de la misma (directores, gerentes o apoderados, empleados) 30 .

De tal modo, el nuevo Art. 31bis del Código Penal español dispone que las personas jurídicas resultarán penalmente responsables de los delitos cometidos en nombre o por cuenta de las mismas, y en su provecho, por sus representantes legales y administradores de hecho o de derecho, así como por aquellos que, en el ejercicio de actividades sociales y por cuenta y en provecho de las mismas, estando sometidos a la autoridad de los administradores sociales o representantes legales, hayan podido realizar los hechos tipificados penalmente por no haberse ejercido sobre ellos el debido control atendidas las concretas circunstancias del caso. La responsabilidad penal será exigible a la persona jurídica siempre que se constate la comisión de un delito que haya tenido que cometerse por quien ostente los cargos o funciones de administración, dirección y representación, aún cuando la concreta persona física responsable no haya sido individualizada o no haya sido posible dirigir el procedimiento contra ella. No obstante, la norma prevé una serie de circunstancias atenuantes de la responsabilidad de la persona jurídica, como son, haber realizado con posterioridad a la comisión del delito y a través de sus representantes legales actividades consistentes en la confesión de la infracción a las autoridades, en la colaboración en la investigación de los hechos delictivos, en haber procedido a la reparación o disminución del daño causado por el delito o en haber establecido medidas eficaces para prevenir y descubrir los delitos que en el futuro pudieran cometerse con los medios o bajo la cobertura de la persona jurídica.

29 Vid. Exposición de Motivos, apartado VII, LO 5/2010.

30 Cfr., Art. 31 del Código Penal español, según el cual, el que actúe como administrador de hecho o de derecho de una persona jurídica, o en nombre o representación legal o voluntaria de otro, responderá personalmente, aunque no concurran en él las condiciones, cualidades o relaciones que la correspondiente figura de delito o falta requiera para poder ser sujeto activo del mismo, si tales circunstancias se dan en la entidad o persona en cuyo nombre o representación obre. 
El Art. 33.7 del Código Penal español establece las penas aplicables a las personas jurídicas, que tienen todas las consideración de graves y van desde la multa por cuotas o proporcional hasta la disolución de la persona jurídica, pasando por -entre otras- la suspensión de sus actividades o la clausura de sus locales y establecimientos por un plazo no superior a cinco años, la prohibición definitiva o temporal (no superior a quince años) de realizar en el futuro las actividades en cuyo ejercicio se hubiera cometido, favorecido o encubierto el delito, la inhabilitación para obtener subvenciones, ayudas públicas, contratar con el sector público o recibir beneficios o incentivos fiscales por plazo no superior a quince años, o la intervención judicial para salvaguardar los derechos de los trabajadores o de los acreedores por plazos no superiores a cinco años.

Parece claro entonces que el legislador europeo y el español han querido relacionar directamente los delitos de corrupción privada y la responsabilidad penal de las personas jurídicas, a sabiendas que en muchas ocasiones esos delitos son cometidos bajo el cobijo que proporciona la personalidad jurídica atribuida a sociedades, fundaciones y asociaciones; y ello sin perjuicio de la responsabilidad personal que pueda corresponder a sus administradores de hecho y de derecho, así como a representantes, directores, colaboradores o empleados por los mismos hechos, siempre que se pueda individualizar al sujeto o sujetos que intervinieran en los actos o hechos concretos.

Pero conviene matizar que la responsabilidad penal de las personas jurídicas sólo podrá prosperar cuando los delitos cometidos (en lo que aquí importa, el delito de corrupción privada) sean realizados por sus administradores, directores, colaboradores, representantes o empleados en nombre y por cuenta de las mismas y en su provecho. Quedan fuera del caso, por tanto, los delitos cometidos por esos sujetos que aprovechan su cargo en la entidad pero que no se hagan en provecho de la misma, así como aquellos que se hagan abusando del cargo en contra de los intereses de la entidad o de aquellos cuyos intereses convergen en la misma (accionistas y socios, trabajadores, acreedores, inversores, ahorradores, asegurados (...)), los cuales podrán perseguirse recurriendo, según los casos, a los delitos de estafa (cfr., Arts. 248-251 del Código Penal español), apropiación indebida (cfr., Arts. 252-254 del Código Penal español) y a los delitos societarios (cfr., Arts. 290-297 del Código Penal español), en particular el delito de administración desleal (Art. 295 del Código Penal español).

\section{Corrupción y Derecho privado patrimonial. Una relación instrumental}

Sin ignorar el papel fundamental que juega el Derecho administrativo y sobre todo el Derecho penal en la lucha contra la corrupción, sea ésta en el sector público o en el sector privado, conocidas las distintas ramificaciones e implicaciones que generalmente llevan asociadas los actos de corrupción, parece que el estudio y la lucha contra estos comportamientos debe abordarse necesariamente desde una 
perspectiva interdisciplinar, abarcado no sólo las disciplinas penal y administrativa, sino también la constitucional, la tributaria, la procesal y -en lo que aquí interesa- la jurídico-privada ${ }^{31}$.

La corrupción, como se ha dicho, consiste en la interposición de un interés privado de naturaleza económica que persigue la desviación ilícita de fondos públicos o privados hacia patrimonios personales o empresariales, se comprenderá fácilmente la existencia necesaria de una relación instrumental entre el fenómeno de la corrupción y el Derecho privado patrimonial.

La presencia de intereses privados económicos como pilar esencial de la economía de la transgresión fruto de la corrupción provoca necesariamente la utilización de instrumentos o instituciones jurídico-privados para la comisión de actos de corrupción y el encubrimiento, desviación y ocultación de los beneficios ilícitos derivados de los mismos. Es lo que podemos calificar como un uso perverso o desviado de las instituciones del Derecho privado; o, para ser más precisos, del Derecho privado patrimonial en cuanto Derecho "económicamente relevante" como lo definiera WEBER ${ }^{32}$. Un moderno Derecho privado patrimonial conformado por las instituciones del Derecho mercantil y del Derecho civil patrimonial, en línea con las últimas tendencias unificadoras dentro del Derecho privado que buscan superar la dicotomía clásica entre Derecho Civil (ius commune) y Derecho Mercantil (lex specialis), como Derecho especial de los empresarios en su actividad, para hablar de un solo Derecho privado del tráfico económico, fruto de la desespecialización y consiguiente generalización de lo mercantil a toda la sociedad: sea por la utilización de instituciones mercantiles por los ciudadanos en sus operaciones económicas privadas ( $c f r$. títulos-valores), sea por la creciente participación de los particulares en las actividades financieras (ahorro e inversión en el mercado financiero), o sea porque el tráfico económico moderno es un tráfico protagonizado esencialmente por la actividad de los empresarios y profesionales del tráfico ${ }^{33}$.

De esta manera, las instituciones del Derecho privado patrimonial se utilizan para dar apariencia de legalidad a operaciones ilícitas de ocultación y desviación de activos y fondos públicos o privados ${ }^{34}, \mathrm{y}$, posteriormente, a las sucesivas operaciones de encubrimiento y reciclaje de los beneficios ilícitos mediante su paulatina

31 La Conferencia de Ministros de Justicia del Consejo de Europa celebrada en La Valette los días 14 y 15 de junio de 1994 declaró que la lucha contra la corrupción en el seno del Consejo de Europa, además de una fuerte cooperación entre Estados, debería seguir una aproximación multidisciplinar, adoptando legislaciones apropiadas en los campos en que resultase necesario. Vid. la exposición de FLORE, L'Incrimination..., cit., pp. 61 y ss.

32 WEBER, M., Economía y Sociedad, Fondo de Cultura Económica, Madrid, 1993, p. 509.

33 Vid. sobre la unificación del Derecho privado en torno a un Derecho del tráfico económico, las reflexiones del maestro BERCOVITZ RODRÍGUEZ-CANO, A., Apuntes de Derecho Mercantil, $10^{\mathrm{a}}$ ed., Thomson-Reuters Aranzadi, 2010, pp. 63 y ss.

34 V.gr., constitución de sociedades u otros entes autónomos instrumentales, como fundaciones, asociaciones o los versátiles "trust" propios, sobre todo, de los ordenamientos países anglosajones; manipulaciones contables; relaciones fiduciarias; simulación contractual; expedición de facturas falsas y otras. 
introducción en los sistemas jurídico-privados de circulación de la riqueza ${ }^{35}$. Se está, en suma, con una instrumentalización abusiva y codiciosa del Derecho privado que entronca necesaria y principalmente con las actividades de corrupción en sus muy diferentes vertientes o posibilidades. Un uso instrumental con fines ilícitos de instituciones jurídico-privadas (uso perverso) para dar apariencia de licitud, es decir, para maquillar operaciones fraudulentas.

Pero en íntima relación con esta instrumentalización negativa del Derecho privado que ha adquirido en los últimos tiempos un nuevo papel protagonista en el ámbito del estudio y la lucha contra la corrupción, en lo que podríamos llamar una instrumentalización positiva del Derecho privado en la lucha contra la corrupción. Y es que, por un lado, el estudio del Derecho privado en relación con este problema de la corrupción permite conocer las lagunas que facilitan el uso perverso de sus instituciones y con ello hacer un seguimiento del circuito patrimonial o financiero de las operaciones económicas ligadas a operaciones ilícitas, que sirven a la investigación patrimonial para detectar la existencia de beneficios ilícitos, su procedencia, origen y destinatario final a los efectos de poder depurar responsabilidades administrativas y penales de los diferentes sujetos implicados, sea en la Administración o sea en la empresa privada. Por otro lado, la investigación permite también la superación gradual de las lagunas normativas que facilitan el uso desviado de las instituciones del Derecho privado patrimonial para cometer actos ilícitos y, así, junto al Derecho administrativo económico, el Derecho Privado -aunque en inferior medida- se revela últimamente como mecanismo de prevención y represión alternativo o complementario a la acción preventiva y represora propia del Derecho administrativo sancionador y del Derecho penal económico.

Hoy día parece haberse caído en la cuenta que constituye un error grave dejar la solución de los problemas planteados por la corrupción pública y privada exclusivamente al "hierro" del Derecho penal, pues a pesar de la alarma social y desconfianza que provocan siempre los actos de corrupción no puede olvidarse el principio de mínima intervención y el carácter de "ultima ratio" de esta disciplina. La represión penal debería venir precedida en lo posible por medidas preventivas de control, tanto de Derecho privado como de Derecho administrativo, sea en instancias públicas o privadas, en aras de la plena transparencia e información en la actuación de los centros de poder y decisión públicos y privados $^{36}$.

35 V.gr., utilización de títulos-valores al portador para la sucesiva circulación de la riqueza, recurso al mercado financiero para el depósito y la inversión en valores y seguros de sumas, aprovechamiento al máximo de las posibilidades del secreto bancario y también del secreto profesional, movilidad e inversión de beneficios ilícitos en los mercados bancarios, mercados de valores, mercados de cambio de divisas y mercados inmobiliarios, entre otros.

36 En esta línea, DEMETRIO CRESPO, E., "Corrupción y Delitos con la Administración Pública”, en FABIÁN CAPARRÓS, E. (Coord.), La Corrupción: Aspectos Jurídicos y Económicos, Ratio Legis, Salamanca, 2000, p. 72. A favor de la prevención también en el terreno del Derecho Administrativo y del Derecho en general para combatir el fenómeno de la corrupción, vid. RIVERO ORTEGA, R., "Instituciones Jurídico-Administrativas y Prevención de la Corrupción”, en FABIÁN CAPARRÓS, E., La Corrupción..., cit., pp. 39 y ss. 
A estos efectos no puede desconocerse la relación de complementariedad que actualmente se produce entre Derecho privado y Derecho administrativo a la hora de diseñar mecanismos preventivos para superar lagunas de las instituciones jurídico-privadas y en pos de la plena transparencia y el correcto funcionamiento del sistema financiero. Junto a normas preventivas de corte estrictamente privado que pueden servir directa o indirectamente para obstaculizar siquiera mínimamente la comisión de actos fraudulentos ${ }^{37}$, es patente también la superposición de normas jurídico-públicas en las instituciones de Derecho privado y en relaciones jurídicoprivadas, como sucede con el control público de entidades de crédito, sociedades de valores y compañías de seguros y de sus operaciones con la clientela, con las obligaciones de divulgación de información financiera para lograr el objetivo de la plena transparencia, con los deberes de conducta en mercados de valores (obligación de divulgar información relevante, establecer filtros entre departamentos de la misma entidad o la prohibición de divulgar y abusar de información privilegiada) o con la prevención de actos de corrupción y de blanqueo o reciclaje de beneficios ilícitos ${ }^{38}$. Esta relación entre Derecho público y privado es característica del Derecho protector de la libre competencia o Derecho "antitrust" y más aún del llamado Derecho del mercado financiero (crédito, valores y seguros) ${ }^{39}$, donde determinadas Agencias o Autoridades Públicas de Control velan por la transparencia e información para el correcto desarrollo y funcionamiento eficiente de los diferentes sectores (Banco de España, Comisión Nacional del Mercado de Valores, Dirección General de Seguros). Se presenta así -por mor de las exigencias de la práctica del mercado moderno- una superación de la summa divissio entre Derecho Público y Privado, al incidir ambas necesaria y estrechamente sobre las mismas materias en algunos casos como los reseñados ${ }^{40}$.

37 V.gr., doble control notarial y registral en la constitución de sociedades, deber de publicidad legal y deberes de contabilidad de los empresarios, aprobación y depósito de cuentas anuales, nombramiento de auditores de cuentas, deber de competencia y prohibición de actos contra la libre competencia y la competencia desleal, abolición de pagarés al portador, deberes de divulgación de información financiera en sociedades anónimas cotizadas y demás.

38 V.gr., obligaciones legales de control e información a entidades financieras como excepción al secreto bancario y deberes de información de notarios y registradores en la lucha contra el blanqueo de capitales, deberes de comunicación e información en entidades que actúan en el mercado financiero, controles de solvencia de intermediarios financieros, deberes de información financiera, deberes de conducta como la prohibición y represión administrativa del abuso de información privilegiada.

39 Para una visión introductoria, sintética y unitaria del Mercado Financiero, remarcando las relaciones y diferencias entre los tres subsectores del crédito, los valores y los seguros, vid. VICENT CHULIÁ, F., Introducción al Derecho Mercantil, 20ª ed., Tirant lo Blanch, Valencia, 2007, pp. 805 y ss.

40 Como apuntó en su día WEBER (Economía y Sociedad, cit., p. 512): "hay que tener en cuenta la posibilidad de que un campo de intereses sea estatuido en tal forma que la creación de pretensiones jurídicas privadas y el establecimiento de poderes de mando u otras funciones orgánicas coexistan relativamente a una misma situación". Los intereses privados y públicos implicados en el correcto y eficiente funcionamiento del sistema financiero es un claro ejemplo. También exige la interdisciplinariedad el estudio y la lucha contra los fenómenos de corrupción pública y privada. 
La comunión de esfuerzos entre mecanismos públicos y privados en sede preventiva de comportamientos abusivos y fraudulentos se deja sentir especialmente en el ámbito de la corrupción privada que tiene lugar en torno a las grandes sociedades anónimas cuyas acciones cotizan en mercados secundarios de valores. Así, a la colosal batería de obligaciones de información exigidas por la normativa legal y reglamentaria (de corte jurídico-público) reguladora de las sociedades cotizadas y de los mercados financieros con la finalidad de lograr el objetivo -básico para el mercado- de la plena transparencia ("full disclosure"), incrementada notablemente en España tras la promulgación de la Ley 44/2002, de 22 de noviembre, de Medidas de Reforma del Sistema Financiero ${ }^{41}$ y las constantes y sucesivas reformas en la Ley 24/1988, de 28 de julio, del Mercado de Valores, se sumaron importantes reformas en la legislación de sociedades de capital para introducir medidas específicas (de naturaleza jurídico-privada) encaminadas a reestructurar y dotar de mayor equilibrio y transparencia los órganos de las sociedades anónimas, a reforzar los deberes y responsabilidad de los administradores en sociedades anónimas y de responsabilidad limitada y a incrementar considerablemente la obligación de información a los socios y accionistas y de divulgación de información patrimonial y financiera relevante al mercado en general, aprovechadas para ello las posibilidades conferidas por las nuevas tecnologías de la información y de la comunicación (TIC) (2 $^{42}$ Reformas estas, por cierto, que vinieron impulsadas por las Recomendaciones plasmadas en los Códigos de Buen Gobierno Corporativo y de transparencia en los mercados de valores que proliferaron en los países desarrollados y en muchos países en desarrollo desde finales de los años 90 del siglo XX, trasladado así al imperio de la Ley lo que en origen no eran más que simples recomendaciones de cumplimiento voluntario ${ }^{43}$.

41 Ley que aumentó considerablemente las obligaciones de transparencia e información en favor de los clientes de servicios financieros y de la transparencia, eficacia y competitividad del sistema financiero en general. Buscaba, en definitiva, avanzar en el proceso de liberalización de mercados (eliminando normativas excesivamente rígidas en el acceso a los mercados) y en la integración de los mercados financieros de la Unión Europea, diseñando un sistema ágil y competitivo, pero cuidando en todo momento por la protección de los clientes de los sistemas financieros, lo cual se consiguió reforzando las obligaciones de diligencia, transparencia e información en las grandes empresas y en los intermediarios financieros, incluyendo las empresas de auditoría de cuentas.

42 En España se han producido importantes reformas en la legislación societaria y de auditoría de cuentas en los últimos años, destacando la Ley 26/2003, de 17 de julio, transparencia de sociedades cotizadas, la Ley 19/2005 sobre la Sociedad Anónima Europea, la Ley 12/2010 de modificación de la legislación sobre auditoría de cuentas, mercado de valores y sociedades anónimas y el muy reciente Texto Refundido de la Ley de Sociedades de Capital 1/2010, de 2 de julio, que regula en un mismo y único texto legal las sociedades anónimas, las sociedades de responsabilidad limitada y las sociedades comanditarias por acciones, unificando muchos de los criterios básicos y contemplando las especialidades de cada tipo social y de sus respectivos subtipos, como son la sociedad limitada nueva empresa y la sociedad anónima cotizada.

43 En España, tras varios documentos preliminares elaborados por Comisiones de expertos, se aprobó, en 2006, por la Comisión Nacional del Mercado de Valores, el Código Tipo Unificado de Buen Gobierno Corporativo. Nos ocuparemos con detalle del Buen Gobierno Corporativo y 
Finalmente no puede obviarse tampoco -como luego veremos in extenso- la posibilidad de que, de forma complementaria o alternativa al Derecho penal ${ }^{44}$, la represión de la corrupción pueda venir también de la mano de mecanismos jurídicoadministrativos $^{45}$ y jurídico-privados ${ }^{46}$. Y ello, ya sea para los casos en que los comportamientos ilícitos inmersos en procesos de corrupción no alcancen la entidad suficiente como para requerir la atención del Derecho penal, o ya como complemento de esa represión penal y de posibles sanciones administrativas para restablecer el daño provocado a las instituciones o a las empresas y particulares que pudieran verse afectados por esos actos corruptos, seguidas así las tesis proclives a la plena

la transparencia en mercados financieros, en relación con la responsabilidad social empresarial, en la segunda parte de este trabajo sobre corrupción en el sector privado, que llevará por título: "Corrupción en el sector privado: Buen Gobierno Corporativo, transparencia y responsabilidad social empresarial”.

44 Por medio de los delitos contra la administración pública y los delitos económicos en general, entre los que se deben incluir los delitos societarios y los delitos relativos a la propiedad intelectual e industrial, al mercado y a los consumidores, el Derecho penal económico muestra su complementariedad en la lucha contra comportamientos ilícitos en el sector privado con el Derecho mercantil y con el Derecho administrativo económico. A ello debe añadirse ahora, como se dijo antes (supra, III.1), la introducción del delito de corrupción entre particulares y la responsabilidad penal de las personas jurídicas.

45 V.gr., régimen jurídico de incompatibilidades y de contratos con las Administraciones públicas, responsabilidad de funcionarios por vulneraciones del procedimiento administrativo especialmente en los concursos públicos de adjudicación de obras y servicios, etc. Destacan especialmente, en aras a la protección del mercado, las sanciones que puedan derivarse de ilícitos contra la libre competencia, como las prácticas colusorias, los abusos de posición dominante y, sobre todo, la concesión de ayudas públicas, de conformidad con la Ley 15/2007, de 3 de julio, de Defensa de la Competencia y su normativa reglamentaria de desarrollo. Y también las sanciones contra los administradores y directivos de entidades crediticias por medio de la Ley 26/1988, de 29 de julio, sobre Disciplina e Intervención de las Entidades de Crédito, aplicable también a los titulares de establecimientos de cambio de moneda y a sus administradores y directivos, ex Art. 36.4 de la Ley 44/2002, de 22 de noviembre, de Medidas de Reforma del Sistema Financiero. Finalmente hay que tener en cuenta la normativa sancionadora de comportamientos prohibidos en los mercados de valores, como puede ser la sanción contra actos que violen la prohibición de abuso de información privilegiada y relevante en mercados de valores, en el Título VII, Arts. 78 y ss. de la Ley 24/1988, de 28 de julio, del Mercado de Valores.

46 Ad ex., la responsabilidad civil derivada del delito (Arts. 109-122 del Código Penal), la responsabilidad civil genérica, contractual y extracontractual, prevista en los Arts. 1101 y 1902 y ss. del Código Civil español, así como los diferentes mecanismos legales o jurisprudenciales específicos o sectoriales de responsabilidad civil, como la responsabilidad de administradores de sociedades de capital (Arts. 236-241 y 367 de la Ley de Sociedades de Capital 2010), la responsabilidad de auditores de cuentas (Art. 271 LSC 2010 y art. 11 de la Ley 19/1988, de 12 de julio, de Auditoría de Cuentas, modificado por la Ley 12/2010), las técnicas del levantamiento del velo de la persona jurídica o la responsabilidad derivada de actos de competencia desleal, ex Arts. 4 y ss. LCD 1991; además, por supuesto, del posible ejercicio de cualesquiera otras acciones civiles que puedan servir para restaurar la situación patrimonial anterior a la comisión del acto de corrupción, como las acciones de nulidad y anulabilidad, acciones rescisorias por fraude de acreedores o acciones de enriquecimiento injusto. 
compensación de daños a los sujetos perjudicados por actos ilícitos, próximas a la doctrina penal de la Justicia Restaurativa.

De esta manera, la represión (y a fortiori, la coerción inducida por ésta) a través de mecanismos jurídico-administrativos y jurídico-privados serviría como elemento de coacción añadido al "yugo" de lo penal, a fin de refrenar los impulsos transgresores de intereses privados egoístas que provocan las oleadas de corrupción que frecuentemente aparecen en las instituciones públicas y en las entidades privadas. En esta línea de plena compensación a los sujetos perjudicados por actos de corrupción parece situarse el importante Convenio del Consejo de Europa, de 4 de noviembre de 1999, de Derecho Civil sobre corrupción, del que ya se habló ${ }^{47}$ y sobre el cual se volverá más adelante ${ }^{48}$.

En los epígrafes siguientes se expone sintéticamente las principales instituciones y técnicas jurídico-privadas que se emplean habitualmente para la comisión de operaciones de corrupción, así como las técnicas privadas y públicas de corte preventivo y represivo que buscan, precisamente, eliminar o reducir ese uso perverso de las instituciones jurídico-privadas, centrándonos en el fenómeno de la corrupción en el sector privado ${ }^{49}$.

\section{Técnicas jurídico-privadas básicas para la comisión, encubrimiento y blanqueo de operaciones de corrupción}

En las operaciones de desvío de fondos o activos procedentes de la Administración o de la empresa privada y en el cobro de comisiones ilegales por los titulares del poder de decisión en cada ámbito, aparece siempre, como requisito casi indispensable, la creación de uno, varios o muchos entes instrumentales (generalmente sociedades mercantiles de capital, anónimas y limitadas, pero también pueden ser fundaciones, cooperativas o asociaciones) $)^{50}$ tras los cuales se esconden directa o indirectamente

47 Vid. supra, II.

48 Vid. infra, V.

49 Razones de espacio impiden abordar con profundidad todos los aspectos de naturaleza y régimen jurídico de las instituciones afectadas, ni tampoco exponer detalladamente el contenido de las medidas preventivas y represivas introducidas por el legislador. Por ello, remitiremos al lector en cada punto de interés a la legislación específica y, como complemento, a trabajos de otros autores que le permitan completar la información y el estudio de las instituciones si así lo desea.

50 Como se dice, lo más habitual es recurrir a la fundación de sociedades de capital, anónimas o limitadas, por la versatilidad y flexibilidad de su estructura societario-capitalista, que hace de ellas hoy día más que organizaciones de un grupo de personas unidas por la finalidad común de explotar una empresa, auténticas organizaciones jurídicas de la empresa misma (y de gestión de patrimonios), incluso sin la necesidad de que exista en su interior una pluralidad de personas, admitida ya la sociedad anónima y limitada unipersonal incluso desde su fundación (vid. CARBAJO CASCÓN, F., La sociedad de Capital Unipersonal, Aranzadi, Pamplona, 2002). La sociedad de capital constituye la herramienta ideal para atraer inversiones y canalizarlas hacia el mundo de 
los beneficiarios de las operaciones de corrupción. Cuando la corrupción se enmarca en redes organizadas es frecuente encontrarse con auténticos grupos o conglomerados de sociedades o entes instrumentales que tienen frecuentemente relaciones económicas entre sí, a través de las cuales se hace circular sucesivamente el dinero ilícito o los activos empresariales para "borrar" la pista de su origen ilícito y, en su caso, "despistar" a los investigadores ${ }^{51}$.

Estas sociedades interpuestas a favor de intereses fraudulentos (sociedades fiduciarias) puede que no realicen ningún tipo de actividad real (sociedades ficticias o sociedades fantasma) que prestan únicamente servicios simulados que nunca llegan a producirse. Pero es posible que sí se realicen actividades reales tras las cuales se reciben, esconden, circulan y se da salida nuevamente a los fondos ilícitos hacia los cauces ordinarios de riqueza; se trata en este caso de sociedades pantalla, empleadas

la empresa y la inversión desligando el patrimonio social (que por la personificación reconocida por el ordenamiento se convierte así en patrimonio autónomo) de la persona de su socio o socios, que pueden variar constantemente. Podrá comprenderse, entonces, el recurso a la creación de sociedades instrumentales para canalizar, mover e invertir los fondos provenientes de operaciones ilícitas. Incluso, en muchas ocasiones, se evita el trámite de la fundación de sociedades (que siempre puede dejar más rastros debido al control notarial-registral), recurriendo a las denominadas compras de capa ("Mantelkauf" en la terminología alemana originaria) que consiste en la compra (a bajo precio) de todas las acciones o participaciones de una sociedad anónima o limitada que existe en el tráfico pero no desarrolla ninguna actividad real, buscando a tal efecto sociedades con objetos sociales relacionados de alguna manera con el sector de la Administración o de la empresa privada en el que actúan quienes quieren llevar a cabo actos de corrupción. Actualmente existen despachos de abogados especializados en la actividad de "compraventa de sociedades", incluso "a la carta" a través de Internet. Es una actividad lícita de la cual, sin embargo, se hace un uso perverso por los agentes económicos y por los propios abogados que buscan así en muchas ocasiones canalizar fondos ilícitos o lícitos (fuga de capitales) hacia terceros países. Es muy habitual en paraísos fiscales como es, por ejemplo, en Europa, Gibraltar o los principados de Andorra y Lichtenstein, donde el número de sociedades domiciliadas es aproximadamente tres veces superior al de las personas físicas censadas.

51 Las sociedades instrumentales se combinan muy habitualmente con el recurso a testaferros y socios fiduciarios o de complacencia ("Strohmann" en la terminología alemana u hombres de paja en la española) en los puestos de socio y de administración (en muchas ocasiones otras sociedades que actúan como socios o administradores siendo a su vez los socios de estas segundas sociedades personas de confianza de los verdaderos responsables de los actos ilícitos), quedando en la sombra el auténtico "dominus societatis" responsable y beneficiario de la operación fraudulenta. Y la movilidad de los fondos ilícitos se hace por medio de contratos simulados, acompañados de la emisión de facturas falsas, que se producen, en primer lugar (para extraer los fondos de su origen) con la Administración (contrato público) o con la empresa privada perjudicada, y después (para mover constantemente los fondos ilícitos) entre diferentes sociedades del mismo grupo, siendo frecuentes los pagos elevados en contraprestación de prestaciones inexistentes (generalmente servicios, de asesoría, consultoría, limpieza, arrendamientos de inmuebles y otros). En España, son particularmente ilustrativas de estas operaciones de corrupción las sentencias de los casos Filesa y Roldán: SSTS (Sala segunda, Penal) de 28 de octubre de 1997 y de 21 de diciembre de 1999 respectivamente. Vid. también, sobre el conglomerado de sociedades instrumentales, el caso Banesto: STS (Sala segunda, Penal) de 29 de julio de 2002. 
para encubrir y blanquear los beneficios de las operaciones de corrupción, llevada una doble contabilidad y computado progresivamente en la oficial (cuentas de la actividad real) los fondos provenientes de la actividad ilícita. Finalmente, es muy frecuente también recurrir a las llamadas sociedades patrimoniales, las cuales actúan como destinatarias finales de los fondos ilícitos que utilizan para invertir en diferentes sectores (mercado de valores, seguros, inmobiliario, joyerías, peleterías, concesionarios de automóviles y demás), para blanquear así la riqueza sucia o ilícita y moviéndola posteriormente a través del sistema financiero internacional hacia destinos más seguros: paraísos fiscales donde prima, por encima de cualquier otra consideración, el secreto bancario, la neutralidad fiscal y la opacidad informativa. Precisamente en la conexión con estos paraísos fiscales es habitual la creación de las llamadas sociedades "off shore" $" 52 \mathrm{y}$, en aquellos ordenamientos que lo permiten, la constitución de algún "trust" y material a priori, se emplean en no pocas ocasiones para instrumentar la fuga de capitales y la ocultación patrimonial y que, por tanto, son habitualmente empleadas en operaciones de corrupción, ya sea como residencia final de capitales ilícitos o ya como instrumentos activos de movimiento de capitales de cara a su reinversión en los cauces económicos ordinarios.

A la hora de hacer circular el capital ilícito para encubrir su origen ilícito y dificultar el seguimiento patrimonial (en el desvío de activos, en la percepción de las comisiones ilegales y en la colocación de los beneficios ilícitos) lo más

52 Estas sociedades que se constituyen en un país, generalmente un paraíso fiscal, con capitales procedentes de terceros países, tienen la indudable ventaja de su total opacidad (anonimato de los accionistas), sus bajos costes de constitución y mantenimiento, la no necesidad de presentar cuentas, la ausencia de control por parte de las autoridades financieras, y, por supuesto, no pagan impuestos o pagan impuestos reducidos. La función de estas sociedades es la de actuar como sociedades patrimoniales (su objeto social se reduce a la gestión de sus activos patrimoniales), pero es frecuente también que actúen en el mismo mercado de origen de su capital, reinvirtiendo así su patrimonio (lícito o ilícito) en el mismo mercado de referencia o en cualquier otro. En Europa, estas sociedades son muy habituales en Gibraltar, captando capital español y reinvirtiendo ese mismo capital en el sur de España (mercados financieros, inmobiliarios, etc.).

53 El "trust" es una figura propia de los Derechos anglosajones que presenta múltiples variedades por su versatilidad para desarrollar diferentes funciones. A grandes rasgos el "trust" permite a una persona (constituyente o fiduciante) la transmisión fiduciaria de un conjunto patrimonial a un tercero (el "trustee" o fiduciario, persona física o jurídica) que recibe la propiedad creando un patrimonio separado de sus propios bienes personales y que se encarga de administrar ese patrimonio en beneficio de otra $u$ otras personas (que puede ser el propio fiduciante o constituyente y/o uno o varios terceros). Vid. sobre la estructura y funciones de esta figura, PENE VIDARI, F., "Trust e rapporti fiduciari tra propietá e contratto", en Rivista Critica del Diritto Privato, Septiembre 2001, pp. 295 y ss. Vid. también, estudiando la posible incorporación del "trust" al Derecho continental europeo, CÁMARA LAPUENTE, S., "El trust y la fiducia: posibilidades para una armonización europea”, en CÁMARA LAPUENTE, S., (Coord.), Derecho Privado Europeo, Colex, Madrid, 2003, pp. 1099 y ss. En algunos países latinoamericanos se contempla, como figura próxima al "trust", la institución del fideicomiso. 
normal, aprovechadas las características de la llamada "sociedad sin caja" ("cashless society") que caracteriza, cada vez más, la sociedad y economía de nuestro tiempo, es postergar el dinero al contado como medio de pago y recurrir a medios ágiles de pago, como son las transferencias electrónicas de fondos y la utilización de títulosvalores, sobre todo -porque es el mejor instrumento para no dejar pistas- los cheques al portador ${ }^{54}$, moviendo así el "dinero bancario" entre diferentes cuentas corrientes abiertas en sucursales distintas de varias entidades de crédito hasta llegar, en última instancia, a cuentas corrientes secretas (numeradas) y blindadas de entidades de crédito domiciliadas en algún paraíso fiscal. Proceso éste de "dispersión progresiva" de la riqueza ilícita (conocido entre las autoridades de blanqueo como "efecto helicóptero") que se ve netamente beneficiado en los últimos tiempos por las amplias posibilidades ofrecidas por la globalización de los mercados $\mathrm{y}$, en concreto, por la expansión de las nuevas tecnologías de la información y de la comunicación que, entre otros efectos beneficiosos (sin perjuicio de su uso perverso), han permitido en poco tiempo la implementación y generalización de los denominados servicios financieros en línea, el dinero electrónico y las transferencias electrónicas de fondos entre entidades de crédito de diferentes países ${ }^{55}$, o incluso entre diferentes sucursales de la misma entidad de crédito con destino final en sucursales de filiales domiciliadas en paraísos fiscales, de cuya operativa no se da cuenta a las autoridades antiblanqueo de los países de procedencia del dinero.

54 En operaciones organizadas de corrupción es habitual ingresar un cheque con dinero ilícito proveniente de la Administración o de la empresa privada en una cuenta corriente de una sucursal bancaria, para después, aprovechando el contrato de cheque adjunto al contrato de cuenta corriente bancaria, dar salida a la cantidad ingresada fraccionada en varios cheques que se utilizan para pagar operaciones simuladas o ficticias y que se ingresarán por su tenedor en una nueva cuenta corriente para dar continuidad a la misma operación de forma sucesiva, o bien simplemente se entregarán en caja en una sucursal bancaria para canjearlos por otros cheques, fraccionando la cuantía del cheque de origen y actuando el banco librado como librador de los mismos para ser cobrados en distintas sucursales (cheques librados contra el propio librador). Finalmente, después de la circulación sucesiva se ingresarán las cantidades en una cuenta corriente abierta a nombre de una sociedad instrumental, pantalla o patrimonial, en pago de alguna contraprestación ficticia, para dar salida al "dinero sucio" hacia los cauces ordinarios del mercado financiero o para emplearlo en operaciones corrientes de mercado en general (compraventa, alquiler, pago de servicios, pago de créditos hipotecarios o de otro tipo, etc.); fase ésta última que sería típica de una operación de blanqueo sucesiva a la de encubrimiento. Vid. un claro ejemplo de esta operación y de las dificultades de su seguimiento por parte de la investigación judicial en la sentencia del caso Roldán: STS de 21 de diciembre de 1999.

55 Una forma habitual de enviar dinero a terceros países con legislaciones más flexibles y favorables en relación con el secreto bancario y la falta de control financiero de la Administración, consiste en la captación de emigrantes para que, por medio de las casas de cambio y transferencias de fondos (muchas veces también con servicios de locutorio telefónico e Internet), hagan envíos periódicos de cantidades reducidas (sin superar los límites impuestos por la legislación pública, en torno a los 3.000 Euros) a cuentas corrientes "supuestamente" abiertas a nombre de sus familiares en sus países de origen o en terceros países. 
En la empresa privada, las operaciones de corrupción parten por lo general de abusos de poder en la gestión empresarial, actúan de manera negligente y desleal con el interés de la empresa, de sus accionistas ("shareholders") y de los trabajadores, acreedores e inversores ("stakeholders"), que infringen claramente los deberes genéricos de diligencia, lealtad y fidelidad de los administradores sociales al interponer sus intereses personales o de terceros a los intereses de la sociedad, seguido de una manipulación contable ${ }^{56}$, abusando de las reglas y principios de valoración fijados legal y reglamentariamente. Manipulaciones contables que, en ocasiones, cuentan con la "inestimable" ayuda (en forma de silencio y omisión de sus funciones públicas de control) de los auditores de cuentas de la empresa que actúan en connivencia con la cúpula directiva de la misma ${ }^{57}$. Los administradores se prevalen en muchas ocasiones del control que directamente (como socios de control de la sociedad) o indirectamente (aprovechadas las posibilidades ofrecidas por el mecanismo de la solicitud pública de representación en grandes sociedades anónimas) ${ }^{58}$ ejercen sobre la Junta General de la sociedad para ratificar o dar apariencia de voluntad social a decisiones que a posteriori se revelan netamente perjudiciales para la sociedad (v.gr., desprenderse de activos por precios inferiores a su valor real presentar o comprar activos por un precio muy superior a su valor real, recibir a cambio comisiones ilegales y maquillar la contabilidad empresarial $)^{59}$.

56 Así, claramente, se aprecia en España, en el caso Banesto (STS de 29 de julio de 2002).

57 Los escándalos de los casos Enron y WorldCom en EE.UU. entre los años 2001-2002 son producto de prácticas contables conocidas como "contabilidad agresiva" o "contabilidad creativa", permitidas por la hasta entonces permisiva legislación estadounidense y que consisten en la falsificación de las cuentas del grupo empresarial distribuyendo sus gastos y pérdidas entre numerosas sociedades filiales cuya contabilidad no se consolida con el conjunto de la corporación o grupo empresarial y computando los beneficios del conjunto de las sociedades del grupo como beneficios de la matriz, consiguiendo así un valor patrimonial positivo en constante crecimiento que sirve para dar una imagen pública de patrimonio consolidado y estable que, a su vez, aumenta la confianza de los inversores e incide directamente en el aumento del valor de cotización de las acciones de la matriz, sirviéndose de ello los administradores y directores para realizar operaciones bursátiles de compraventa de valores (incluyendo programas de opciones sobre acciones como remuneraciones en especie) que les permitieron enriquecerse en poco tiempo a costa del resto de accionistas de la empresa y de los intereses generales. Vid. el trabajo de BETANCOR, A., "Enron, liberalización, nueva economía", Política Exterior, No. 86, 2002, pp. 59 y ss.

58 Cfr., art. 186 del Texto Refundido de la Ley de Sociedades de Capital española de 2 de julio de 2010 (LSC).

59 Estas irregularidades contables se encuentran relacionadas en muchas ocasiones con políticas de evasión de impuestos, jugando con las posibilidades ofrecidas por la legislación fiscal para fomentar la inversión (beneficios fiscales relacionados con fondos de inversión, planes de pensiones, etc.) con la intención última de acumular beneficios no computados en cuentas ocultas que posteriormente se utilizan para remuneraciones directas o en especie de los directivos (v.gr., invertir beneficios en fondos de inversión inexistentes con la finalidad de eludir impuestos y poner a recaudo esas cantidades en cuentas de paraísos fiscales, con la intención de revertir esos beneficios a la cúpula directiva de la empresa por medio de planes de jubilación, cuotas en fondos de inversión, seguros 
Es imposible, en fin, abordar aquí todas las operaciones fraudulentas que implican un uso perverso de las instituciones mercantiles, ya que pueden ser de lo más variado. Por ejemplo, una forma especial de instrumentalización negativa del crédito consiste en la concesión abusiva de crédito a terceros (o socios o administradores de la misma entidad prestamista) sin estudio de riesgo y con condiciones excesivamente favorables para el prestatario que acaban por fomentar la morosidad e incluso situaciones de insolvencia abocadas al concurso de acreedores, con el consiguiente perjuicio para los grupos de intereses implicados en la organización prestamista. Actividad ésta típica de las entidades crediticias (que incluso, en ocasiones se ha utilizado como operación de blanqueo de beneficios ilícitos) pero que puede producirse también en cualesquiera sociedades o entidades independiente de su objeto social.

\section{Medidas de prevención y represión de la corrupción. El papel del derecho privado}

\section{La prevención: medidas coercitivas en el plano administrativo y privado}

La utilización perversa de las instituciones jurídico-mercantiles y de la propia estructura organizativa de la empresa privada para cometer actos de corrupción encuentra, sin duda, su respuesta más contundente en el Derecho penal. No obstante, como se dijo antes, no puede confiarse la represión de todos los comportamientos abusivos y fraudulentos a la coerción que supone la gravedad inherente a las sanciones penales.

El principal freno a la corrupción debe venir desde la prevención. No cabe duda, desde esta perspectiva, que la amenaza que conlleva el Derecho penal contribuye notablemente a prevenir comportamientos ilícitos. Del mismo modo, el Derecho administrativo sancionador también sirve para prevenir comportamientos que no merezcan la represión punitiva.

En el plano jurídico-público, además del tradicional régimen de incompatibilidades de funcionarios públicos (que contiene especiales referencias a la participación de éstos en sociedades interpuestas) y las normas de buen gobierno de los altos cargos

de vida, etc., a modo de remuneración en especie). También se relacionan en otras muchas ocasiones con operaciones de concentración empresarial o toma de control de terceras empresas (v.gr., manipulación contable para reducir el valor patrimonial de la empresa y el valor real de las acciones a fin de favorecer una OPA por parte de un tercero aprovechando la volatilidad de los precios en los mercados secundarios de valores). 
de la Administración del Estado ${ }^{60}$, existen importantes medidas de prevención que afectan al sector privado, comenzando por las facultades de control, vigilancia, inspección y sanción de las Autoridades que se encargan de velar por la transparencia $\mathrm{y}$ el correcto funcionamiento de los mercados financieros, en sus vertientes de crédito, valores y seguros ${ }^{61}$, plasmadas en normas de importancia decisiva para el correcto funcionamiento del sistema financiero como son la Ley 26/1988, de 29 de julio, sobre Disciplina e Intervención de las Entidades de Crédito, la Ley 24/1988, de 28 de julio, de Mercado de Valores, el Texto Refundido de la Ley de Ordenación y Supervisión de los Seguros Privados, aprobado por el Real Decreto Legislativo 6/2004, de 29 de octubre y la Ley 19/1988, de 28 de julio, del Mercado de Valores con su normativa reglamentaria de desarrollo ${ }^{62}$.

60 Las normas de Derecho privado contienen algunas previsiones aisladas sobre incompatibilidades (cfr. Arts. 13 y 14 Ccom español de 1885 y el Art. 213.2 del Texto Refundido de la Ley de Sociedades de Capital de 2010. No obstante, en España el verdadero régimen jurídico de las incompatibilidades se encuentra en las leyes especiales jurídico-administrativas y en concreto en la Ley 53/1984, de 26 de diciembre, de incompatibilidades del personal al servicio de las administraciones públicas. También el Acuerdo del Consejo de Ministros, de 18 de febrero de 2005, por el que se aprueba el Código de Buen Gobierno de los miembros del Gobierno y de los Altos Cargos de la Administración General del Estado, en el cual se indica que los Ministros y Altos Cargos de la Administración del Estado se abstendrán de toda actividad privada o interés que pueda suponer un riesgo de plantear conflictos de intereses con su puesto público, entendiéndose que existe conflicto de intereses cuando los altos cargos intervienen en las decisiones relacionadas con asuntos en los que confluyan a la vez intereses de su puesto público e intereses privados propios, de familiares directos, o intereses compartidos con terceras personas. Estas medidas se reforzaron con la aprobación de la Ley 5/2006, de 10 de abril, de regulación de los conflictos de intereses de los miembros del Gobierno y de los Altos Cargos de la Administración General del Estado, la cual no se presenta como una mera reproducción de la Ley de incompatibilidades, sino que incrementa la prevención de conflictos de intereses en los altos cargos gestores del Estado. En el ámbito de la gestión pública local, la Federación Española de Municipios y Provincias aprobó el Código de Buen Gobierno Local en forma de recomendaciones a las entidades locales, siguiendo las Recomendaciones aprobadas en 1999 por el Congreso de Poderes Locales y Regionales del Consejo de Europea. En la actualidad el Gobierno español trabaja en la aprobación de una Ley sobre Buen Gobierno y Administración Local.

61 V.gr., control de condiciones de solvencia por parte del Banco de España y la Dirección General de Seguros a entidades y establecimientos financieros de crédito y compañías de seguros respectivamente, procedimientos de auditoría de empresas de servicios de inversión por la Comisión Nacional del Mercado de Valores, normas de conducta en los mercados de valores y demás.

62 No obstante, a pesar de las amplias facultades de control, inspección y sanción de las Autoridades de control de los mercados financieros, en los últimos años se han producido en España graves escándalos financieros (como los de los casos Gescartera en el mercado de valores y Eurobank en el mercado crediticio) que producen graves distorsiones en el funcionamiento eficiente del sistema financiero. Estos escándalos sólo pueden achacarse a la propia negligencia de las autoridades de control, sea por no detectar a tiempo el problema (como ocurrió en Gescartera), o sea por no actuar con la contundencia necesaria antes de que se produzca la crisis definitiva de la entidad inspeccionada (como ha sucedido en Eurobank). En estos casos el recurso último de los perjudicados (inversores, depositantes) pasa por exigir la responsabilidad patrimonial de la Administración y, en su caso, responsabilidad penal y civil a las personas que se hubieran lucrado con estas crisis. 
De notable importancia también en relación con el sector privado es la normativa relativa al blanqueo de capitales, que pretende prevenir las operaciones de encubrimiento y blanqueo en sus diferentes fases de colocación (introducción de fondos ilícitos en el sistema financiero), conversión (desarrollo sucesivo de operaciones financieras para distanciar los bienes de su origen ilícito) e integración (reintroducción de los beneficios ilícitos en los cauces económicos regulares que aportan una apariencia de legalidad), imponiendo importantes obligaciones de información a intermediarios financieros mediante límites explícitos al secreto bancario63, así como a otras organizaciones o entidades y profesionales liberales (casinos de juego, promotoras inmobiliarias, corredores inmobiliarios) cuyas actividades son proclives al movimiento y reciclaje de fondos ilícitos provenientes de operaciones de corrupción aislada u organizada. En este campo destaca, además de numerosos instrumentos internacionales de diversas instituciones (FMI, Banco Mundial), y en especial las Recomendaciones del Grupo de Acción Financiera (GAFI) sobre lavado de activos, aprobadas en 1990 y revisadas en varias ocasiones en los años siguientes. En el ámbito de la Unión Europea destacan la Directiva 91/308/ CEE del Consejo, de 10 de junio, relativa a la prevención de la utilización del sistema financiero para el blanqueo de capitales, modificada por la Directiva 2001/97/CE del Parlamento Europeo y del Consejo, de 4 de diciembre, así como la Directiva 2005/60/ CE del Parlamento Europeo y del Consejo, de 26 de octubre de 2005, relativa a la prevención de la utilización del sistema financiero para el blanqueo de capitales y para la financiación del terrorismo, desarrollada por la Directiva 2006/70/CE de la Comisión, de 1 de agosto de 2006, así como el Reglamento (CE) No. 1781/2006, del Parlamento Europeo y del Consejo, de 15 de noviembre de 2006, relativo a la información sobre los ordenantes que acompaña a las transferencias de fondos.

63 Hoy día parece asociarse la naturaleza del secreto bancario con el derecho fundamental a la intimidad previsto en el Art. 18.1 de la Constitución Española (cfr. STC 110/1984, de 26 de noviembre y otras posteriores). No obstante puede decirse que se trata de una cuestión que ha perdido fuerza en los últimos años debido a las estrictas limitaciones impuestas al mismo por medio de la legislación antiblanqueo. A estos efectos, puede decirse que son más importantes los límites al secreto bancario que la propia institución del secreto bancario como tal. El hecho de relacionarlo con un derecho fundamental no significa que no pueda ser limitado. Evidentes consideraciones de política jurídica y la implicación de los intereses generales aconsejan su limitación. Otra cosa es la importancia del secreto bancario en las relaciones con terceros países donde se respeta a ultranza (paraísos fiscales), siendo la única vía para salvarlo de cara a la investigación de actos de corrupción los mecanismos procesales acordados en convenios internacionales ( $c f r$. comisiones rogatorias, etc.), así como instrumentos de cooperación en materia de intercambio de información financiera (vid. a estos efectos la Decisión del Consejo, de 17 de octubre de 2000, relativa a las disposiciones de cooperación entre las unidades de información financiera de los Estados miembros para el intercambio de información). Sobre el secreto bancario y sus límites, vid., entre otros, GUILLÉN FERRER, Ma. J., El Secreto Bancario y sus Límites Legales (Limites de Derecho Público), Tirant lo Blanch, Valencia, 1997; también, AZAUSTRE FERNÁNDEZ, Ma. J., El secreto Bancario, Bosch, Barcelona, 2001; finalmente, GONZÁLEZ CUSSAC, J.L, (Dir.), Financiación del terrorismo, blanqueo de capitales y secreto bancario, Tirant lo blanch, Valencia, 2009. 
En España fue fundamental la Ley 19/1993, de 28 de diciembre, sobre determinadas medidas de prevención del blanqueo de capitales, desarrollada reglamentariamente por el RD 925/1995, de 9 de junio, y modificada luego por la Ley 19/2003, de 4 de julio, sobre régimen jurídico de los movimientos de capitales y de las transacciones económicas con el exterior y sobre determinadas medidas de prevención del blanqueo de capitales ${ }^{64}$. En la actualidad, el régimen de lucha y prevención contra el blanqueo de capitales se rige por la Ley 10/2010, de 28 de abril, de prevención del blanqueo de capitales y de la financiación del terrorismo, que incorpora en España la Directiva 2005/60/CE, adaptando así a las nuevas circunstancias sociales y económicas globales el régimen del lavado de activos. Resulta de especial importancia el listado de sujetos obligados a proporcionar la información y colaboración (medidas de diligencia debida) exigidas por la Ley (cfr., art. 2), que incluyen entidades de crédito, compañías y corredores de seguros en seguros de vida y otros seguros de sumas o inversiones, empresas de servicios de inversión (sociedades y agencias de valores), sociedades gestoras de instituciones de inversión colectiva (como fondos y sociedades de inversión mobiliaria e inmobiliaria), entidades gestoras de fondos de pensiones, entidades de capital-riesgo, sociedades de garantía recíproca, entidades de medios de pago, personas que ejerzan profesionalmente actividades de cambio de moneda, servicios postales en actividades de giro o transferencia de fondos, personas y entidades dedicadas profesionalmente a la intermediación en la concesión de préstamos o créditos, promotores inmobiliarios e intermediarios en la compraventa de bienes inmuebles, auditores de cuentas, contables externos y asesores fiscales, notarios y registradores de la propiedad, mercantiles o de bienes muebles, casinos de juego, personas y entidades que comercien con joyas, piedras o metales preciosos, objeto de arte o antigüedades, personas responsables de la gestión, explotación y comercialización de loterías o juegos de azar, así como los abogados, procuradores $\mathrm{u}$ otros profesionales independientes cuando participen en la concepción, realización o asesoramiento de operaciones por cuenta de clientes relativas a la compraventa de bienes inmuebles o entidades comerciales, la gestión de fondos, valores u otros activos, la apertura o gestión de cuentas corrientes, cuentas de ahorros o de valores, la organización de las aportaciones necesarias para la creación, el funcionamiento o la gestión de empresas o de fideicomisos ("trust"), sociedades o estructuras análogas o cuando actúen por cuenta de clientes en cualquier operación financiera o inmobiliaria ${ }^{65}, \mathrm{y}$ también las personas que con carácter profesional presten a terceros

64 Normativa que sustituye también el trasnochado régimen de la Ley 40/1979, de 10 de diciembre, sobre Régimen Jurídico de Control de Cambios, derogado de facto por el principio comunitario de libre circulación de capitales tras la entrada de España en las Comunidades Europeas en 1986 (Art. 56 del Tratado de Roma, actualmente Art. 63 del Tratado de Funcionamiento de la Unión Europea) y más aún por las tendencias liberalizadoras y globalizadoras de la economía mundial, sustituyendo las restricciones por exigencias de información y algunas prohibiciones para casos excepcionales.

65 Especialmente problemática, en relación con el secreto profesional, resulta la sujeción de auditores, contables externos y asesores fiscales, además de notarios, abogados y procuradores, a obligaciones 
servicios relacionados con la constitución y gestión de sociedades u otras personas jurídicas, ejercer funciones de fideicomisario en un fideicomiso o ejercer funciones de socio o accionista por cuenta de otra persona.

Son relevantes también las obligaciones de información impuestas (con amenaza de sanción) a Notarios y Registradores por medio de la Instrucción de la Dirección General de Registros y del Notariado, de 10 de diciembre de 1999, así como la Resolución de 30 de noviembre de 2004 de la Dirección General de los Registros y del Notariado, relativa al cumplimiento de la Instrucción de 10 de diciembre de 1999, sobre las obligaciones de los Notarios y Registradores de la Propiedad y Mercantiles en materia de prevención del blanqueo de capitales, las cuales tienen por objetivo la averiguación de operaciones sospechosas en materia de blanqueo de capitales, principalmente en relación con operaciones de constitución o adquisición de sociedades mercantiles, utilización de fiduciarios (testaferros) como socios o administradores y también en relación con operaciones del mercado inmobiliario, mediante la colaboración de notarios y registradores por su intervención necesaria en la constitución de sociedades (doble control de legalidad notarial-registral) y en el mercado inmobiliario (escritura pública para acceso al registro de la propiedad).

En materia de títulos-valores, y en concreto de la emisión de cheques como medio de pago y de circulación de la riqueza, existen normas fiscales ( $c f r$. Art. 84 Ley 31/1991, de 30 de diciembre) dirigidas a establecer algunos controles de información, como son la prohibición de librar cheques contra efectivo, valores u otros cheques sin la comunicación del número de identificación fiscal (NIF) del tomador, quedando así constancia del libramiento y de la identidad del tomador, o también la obligación para las entidades de crédito de exigir la comunicación del NIF a la persona o entidad que presente al cobro cheques emitidos por una entidad de crédito o bien librados por personas o entidades distintas en cuantías superiores a 3.000 euros y dejar constancia del pago del cheque y de la identidad de la persona que lo presentó al cobro, que serán trasladados a la Administración tributaria ${ }^{66}$.

Ya en el ámbito estrictamente jurídico-privado (aunque es apreciable la concurrencia de medidas preventivas de naturaleza mixta, privada y administrativa), y siguiendo la senda marcada por la Convención de Naciones Unidas contra la Corrupción (cfr., Art. 12), encontramos medidas preventivas contra la corrupción en el sector privado, por ejemplo, en las obligaciones contables introducidas para todos los empresarios mercantiles (obligaciones formales de llevanza de libros contables,

de información a las autoridades de prevención del blanqueo de capitales sobre cualquier hecho u operación del que resulte indicio o certeza de que está relacionado con el blanqueo de capitales.

66 Debe destacarse en este ámbito la Ley 16/2009, de 13 de noviembre, de servicios de pago, cuyo finalidad es la de regular los distintos servicios de pago existentes en el mercado español, incluida la forma de prestación de dichos servicios, el régimen jurídico de las entidades de pago, el régimen de transparencia e información aplicable a los servicios de pago, así como los derechos y obligaciones respectivas tanto de los usuarios de los servicios como de los proveedores de los mismos. 
Arts. 25-33 Ccom., y obligaciones materiales de elaboración y presentación de las cuentas anuales, Arts. 33-41 Ccom.), y especialmente (por su mayor incidencia en el tráfico moderno) las obligaciones contables de las sociedades de capital (arts. 253-284 de la Ley de Sociedades de Capital), destacando además por su especial importancia la obligación de consolidación contable de los grupos de sociedades (Arts. 42-49 Ccom. ${ }^{67}$. La normativa contable ha sido modificada de manera importante a raíz de la aprobación de las Normas Internaciones de Información Financiera (NIIF), plasmadas para Europa en el Reglamento (CE) No. 1606/2002, del Parlamento Europeo y del Consejo, de 19 de julio de 2002, y que han sido incorporadas al ordenamiento español por medio de la Ley 16/2007, de 4 de julio, que ha modificado de manera importante los arts. 25 a 49 del Código de Comercio. En el ámbito de la verificación contable, tan relevante para conseguir la plena transparencia financiera de las grandes empresas (como dejó claro el escándalo Enron-Andersen), resultan significativas como medidas preventivas, en primer lugar, la obligación de las sociedades anónimas emisoras de valores que cotizan en mercados bursátiles de crear un Comité de Auditoría dentro de su órgano de administración; obligación establecida por el art. 47 de la Ley de Reforma del Mercado Financiero que añade una Disposición adicional decimoctava a la LMV, la cual ha sido modificada por la reciente Ley 12/2010, de 30 de junio, para reforzar el papel de la auditoría como factor de prevención. Asimismo, esta Ley 12/2010 ha reformado profundamente la Ley 19/1988, de 12 de julio, de Auditoría de Cuentas (LAC), para reforzar las condiciones y requisitos de necesaria observancia para su ejercicio, así como la regulación del sistema de supervisión pública y los mecanismos de cooperación internacional en relación con dicha actividad. Entre otras medidas concretas relativas al ejercicio de la profesión de auditor, la legislación sobre auditoría de cuentas establece normas estrictas sobre independencia de los auditores (Arts. 8 a 8 ter LAC), sobre contratación y rotación de auditores en las empresas sometidas obligatoria o voluntariamente a auditoría (Art. 8 quáter LAC), sobre la prohibición para formar parte de los órganos de dirección de sociedades auditadas anteriormente (art. 8 quinquies LAC) o sobre fijación de honorarios (Art. 8 sexies LAC), así como deberes de secreto (Art. 13 LAC), de conservación y acceso a la documentación (Art. 14 LAC) y de transparencia (mediante la obligación de elaborar y hacer público a través de Internet un informe de auditoría de las entidades de interés público (Art. 14 bis LAC).

67 Además de las obligaciones de elaboración de cuentas siguiendo la estructura contable prevista en las leyes y de la presentación de las cuentas, aprobación y depósito en el Registro mercantil bajo sanción de cierre del registro para actos y negocios posteriores (Art. 282 LSC), es de singular importancia el respeto a las reglas de valoración contable, para evitar los casos de contabilidad creativa que explotaron tras el caso Enron y que ha obligado a una modificación normativa importante. Vid. sobre este complejo y a la vez fundamental aspecto del funcionamiento societario y empresarial en general, el trabajo de DE TORRES ZAPATERA M., Valores ocultos en las cuentas anuales, Civitas, Madrid, 2002. 
Igualmente pueden considerarse normas preventivas jurídico-privadas la moderna regulación introducida en el ámbito de las sociedades mercantiles de capital, fundamentalmente en las sociedades anónimas cotizadas. Destacan entre otras las modificaciones introducidas por la Ley 26/2003, de 17 de julio, por la que se refuerza la transparencia de las sociedades anónimas cotizadas, las cuales han sido reorganizadas y reforzadas en el vigente Texto Refundido de la Ley de Sociedades de Capital de 2 de julio de 2010 (LSC), incluidos nuevos deberes de los administradores para los casos de ejercicio del derecho de voto por administradores en caso de solicitud pública de representación en la celebración de las Juntas Generales (Art. 514 LSC) que exige la elaboración de un reglamento de régimen interno de organización y funcionamiento de la Junta General (Arts. 512 y 513 LSC) y del Consejo de Administración (Arts. 516 y 517 LSC), así como la elaboración y difusión de un informe anual de gobierno corporativo como pieza separada en el informe de gestión que acompaña a las cuentas anuales de las sociedades cotizadas (Art. 526 LSC), la obligación de disponer de un sitio web para difundir la información relevante exigida por la legislación del mercado de valores (Art. 528.2 LSC) o la obligación de dar publicidad de pactos parasociales en las sociedades anónimas (Arts. 518-523 LSC); y, en general, reforzando los deberes fiduciarios de los administradores de sociedades anónimas y de responsabilidad limitada, creando, junto al tradicional deber de diligencia o diligente administración de un ordenado empresario (que incluye ahora la información diligente sobre la marcha de la sociedad, Art. 225 LSC), unos deberes de lealtad en defensa del interés social (Arts. 227-231 LSC) y un deber de secreto aun después de cesar en las funciones de administrador (Art. 232 LSC), y aclarando los criterios de responsabilidad por daños y perjuicios de los administradores de las sociedades de capital, que se hacen extensivos a los administradores de derecho y de hecho (Arts. 236-241 LSC), y que resultan complementados con la responsabilidad de administradores por no promover la disolución de la sociedad sobre todo en caso de descapitalización (Art. 367 LSC) y con la responsabilidad de administradores en caso de concurso de la sociedad prevista en la legislación concursal (Arts. 48.2 y 172.3 de la Ley 22/2003, de 9 de julio, Concursal).

Este riguroso estatuto de deberes y responsabilidades de los administradores de sociedades de capital (que constituye una manifestación clara del movimiento neo-regulador que pretende atemperar los defectos y vicios propios de una excesiva permisividad neoliberal en la organización y gestión de sociedades mercantiles) se refuerza en el caso de sociedades anónimas cotizadas con la progresiva adopción de Códigos de Buen Gobierno Corporativo y transparencia ante los mercados de valores, cuyo objetivo no es otro que el de promover -por medio de meras recomendacionesla introducción voluntaria de elementos éticos en la gestión empresarial y contribuir a incrementar la transparencia y la buena imagen de la sociedad ante sus accionistas y ante los inversores y ciudadanos en general, para reforzar así la seguridad jurídica y 
la confianza en los operadores económicos y en el sistema económico en general ${ }^{68}$. A los aspectos relativos al Buen Gobierno Corporativo, tanto desde la perspectiva legal como de la autorregulación, se debe sumar ahora el movimiento de la Responsabilidad Social Empresarial, que se aprecia cada vez más como un compromiso de la empresa con su entorno susceptible de encuadrarse en políticas de gobierno corporativo ${ }^{69}$.

\section{La represión: mecanismos penales, administrativos y jurídico privados}

Al entrar en las medidas represivas de los actos de corrupción en que interviene la empresa privada, se debe atender en primer lugar al Derecho Administrativo sancionador, y en concreto a las potestades atribuidas por las diferentes legislaciones a las Autoridades públicas o Agencias de control de los mercados financieros (Banco de España, Comisión Nacional del Mercado de Valores y Dirección General de Seguros), a las autoridades de prevención y represión del blanqueo de capitales, a las autoridades de control de la libre competencia (Comisión Nacional de Competencia) y en último término al Ministerio de Economía.

Pueden resultar también de singular importancia los ilícitos contra la libre competencia ("antitrust") incluidos en la normativa comunitaria y española sobre libre competencia (Arts. 101 y ss. del Tratado de Funcionamiento de la Unión Europea y la Ley española 15/2007, de 3 de julio, de Defensa de la Competencia), tanto en el ámbito de los acuerdos prohibidos o prácticas colusorias como en el del abuso de posiciones de dominio y, también, con especial atención (por la mezcla de intereses públicos y privados que subyace siempre a la corrupción) al problema de las ayudas públicas (Arts. 107-109 TFUE y Art. 11 LDC) $)^{70}$. Téngase en cuenta, en este sentido, que los instrumentos internacionales de lucha contra la corrupción mencionan constantemente que tanto la corrupción pública como la corrupción

68 Sobre el Buen Gobierno Corporativo en las sociedades cotizadas en España, pueden consultarse los informes Olivencia y Aldama y el Código Unificado de Buen Gobierno Corporativo publicado por la CNMV en 2006. En la doctrina científica vid. por todos ESTEBAN VELASCO G., (Coord.), El Gobierno de las Sociedades Cotizadas, McGraw Hill, Madrid, 1999; también AA.VV., Derecho de Sociedades Anónimas Cotizadas, Thomson-Aranzadi, 2006.

69 Como ya dijimos antes, del buen gobierno y la responsabilidad social empresarial nos ocuparemos específicamente en la segunda parte de este trabajo sobre corrupción en el sector privado.

70 Sin duda, está más desarrollado el tratamiento de las ayudas públicas en el Derecho comunitario de la competencia que en el Derecho nacional. A estos efectos, y a la vista de la incidencia que las ayudas a empresas públicas puede tener respecto a distorsiones de la competencia en el mercado, téngase en cuenta también la Directiva 2000/52/CE, de 26 de julio de 2000, relativa a la transparencia de las relaciones financieras entre los Estados miembros y las empresas públicas. En la doctrina, vid. la obra de ARPIO SANTACRUZ, J.L, Las Ayudas Públicas ante el Derecho europeo de la competencia, Aranzadi, Navarra, 2000. 
privada es un factor de inestabilidad de la libre competencia en el mercado, lo cual quiere decir que los sobornos activos y pasivos pueden considerarse actos contrarios a la libre competencia y, por tanto, ser perseguidos como tales por las autoridades administrativas y judiciales encargadas de aplicar el Derecho antitrust.

En el terreno específico de la represión de la corrupción por el Derecho privado destaca el capítulo relativo a las indemnizaciones de daños y perjuicios derivados de actos de corrupción ${ }^{71}$.

En la línea de la plena restauración o compensación de los daños y perjuicios sufridos por terceros sujetos se enmarca el tantas veces citado Convenio del Consejo de Europa, de 4 de noviembre de 1999, de Derecho Civil sobre corrupción, según el cual - como vimos ${ }^{72}$ - cada Estado firmante debe proveer en su ordenamiento interno remedios efectivos para personas que hayan sufrido un daño como consecuencia de actos de corrupción, a los efectos de defender sus derechos e intereses mediante el ejercicio de acciones encaminadas a obtener plena compensación de los daños sufridos tanto materiales como no pecuniarios (cfr. Arts. 1-4). También se obliga a las partes firmantes a prever en su ordenamiento interno procedimientos adecuados para que las personas perjudicadas por actos de corrupción cometidos por funcionarios o cargos públicos en el ejercicio de sus funciones puedan reclamar compensaciones al Estado u Organizaciones no estatales (cfr., Art. 5). En esa misma línea se sitúa la Convención de Naciones Unidas sobre Corrupción, de 31 de octubre de 2003, la cual dispone con carácter general que los Estados parte deberán adoptar medidas necesarias, de conformidad con los principios de su Derecho interno, para garantizar que las entidades o personas perjudicadas como consecuencia de un acto de corrupción tengan derecho a iniciar una acción legal contra los responsables de esos daños y perjuicios a fin de obtener indemnización (cfr., Art. 35). Asimismo obliga a los Estados parte a adoptar las medidas necesarias para establecer la responsabilidad de personas jurídicas por su participación en delitos de corrupción, la cual podrá ser de índole penal, administrativa o civil y existirá sin perjuicio de la responsabilidad penal que incumba a las personas naturales que hubieran cometido tales delitos (cfr., Art. 26).

Parece, por tanto, que los Estados firmantes de estos Convenios regionales e internacionales están obligados a ofrecer los medios necesarios para procurar el

71 Ello además, sin perjuicio de la posibilidad, ya comentada (supra II), de solicitar la nulidad de los contratos o cláusulas contractuales que tengan por objeto un acto de corrupción, así como de la facultad de las partes contratantes cuyo consentimiento esté viciado por actos de corrupción (por la intervención fraudulenta de un representante legal o un administrador o gestor competente para celebrar esos contratos) de solicitar judicialmente la declaración de nulidad de esos contratos, sin perjuicio, además, de su derecho a reclamar la indemnización de daños y perjuicios, tal y como dispone el Art. 8 del Convenio del Consejo de Europa de Derecho Civil sobre Corrupción, de 4 de noviembre de 1999. En esta misma línea se pronuncia la Convención de Naciones Unidas sobre Corrupción, de 31 de octubre de 2003 (cfr., Art. 34).

72 Supra, II. 
pleno resarcimiento de los perjudicados por actos de corrupción, sea de agentes o funcionarios de la Administración pública, o sea dentro de la empresa privada, disponen de mecanismos materiales y procesales suficientes para permitir a los damnificados la posibilidad de ejercer acciones penales, administrativas y civiles no sólo contra las personas físicas responsables directas de la corrupción sino también contra la Administración pública correspondiente y contra las empresas privadas (generalmente sociedades mercantiles) o personas jurídico-privadas en general (fundaciones, asociaciones) en cuyo nombre y provecho se hubieran cometido esos actos de corrupción activa o pasiva.

Pues bien, aunque actualmente los ordenamientos modernos ofrecen a los perjudicados por actos de corrupción distintas soluciones para reclamar indemnizaciones por daños y perjuicios a quienes cometan actos de corrupción activa y pasiva, así como a las personas jurídicas que se pudieran beneficiar de actos de corrupción en las relaciones con la Administración o con otras empresas o entidades privadas, podría resultar conveniente, para cumplir con las obligaciones asumidas en los Convenios regionales e internacionales, clarificar en el ordenamiento la posibilidad de resarcirse plenamente de los daños y perjuicios derivados de actos de corrupción, por ejemplo, modificando el Código Civil en materia de responsabilidad extracontractual para reconocer legitimación activa a los particulares perjudicados directa o indirectamente por actos de corrupción en el sector público o en el sector privado para ejercitar acciones indemnizatorias de daños y perjuicios contra todos aquellos, personas físicas y jurídicas, que hubieran cometido o se hubieran beneficiado de actos de corrupción activa o pasiva.

Conocida la habitual intervención del Derecho penal en la represión de casos de corrupción en el sector público mediante los delitos de cohecho (Art. 419 del Código Penal español), tráfico de influencias (Art. 428 del Código Penal español), malversación de fondos (Art. 432 del Código Penal español) y corrupción en las transacciones comerciales internacionales (Arts. 445 y 445bis del Código Penal español); y ahora también (tras la tipificación del delito de corrupción entre particulares y el reconocimiento de la responsabilidad penal de las personas jurídicas en los Códigos Penales de los Estados miembros de la Unión Europea) en la represión de la corrupción en el sector privado (cfr., Art. 286bis del Código Penal español $)^{73}$, debe partirse en primer lugar de las normas sobre responsabilidad civil derivada del delito recogidas en el Título V del Libro I, Arts. 109-126 del Código Penal español. En relación con estas normas se hace preciso reseñar que, a pesar de la regulación específica en el Código Penal de la responsabilidad civil ex delicto y de su conocimiento por el Juez penal, conviene tener claro que, en todo caso, "la responsabilidad civil es precisamente una cuestión de orden exquisitamente

73 Vid. supra, III.1. 
civil" 74 . De hecho, el perjudicado podrá optar por dejar que sea el Juez penal quien se pronuncie sobre la responsabilidad o por reservar el ejercicio de las acciones de responsabilidad civil que pudieran derivar del delito ante la Jurisdicción civil (Art. 109.2 Código Penal español).

El Art. $120.4^{\circ}$ del mismo Código Penal español prevé la responsabilidad civil subsidiaria de las personas naturales o jurídicas por los delitos o faltas que hayan cometido sus empleados o dependientes, representantes o gestores en el desempeño de sus obligaciones o servicios ${ }^{75}$. El nuevo Art. 116.3 del Código Penal español, añadido por la ya citada Ley 5/2010, de reforma del Código Penal, dispone -en línea con el reconocimiento de la responsabilidad penal de las personas jurídicas- que la responsabilidad penal de una persona jurídica llevará consigo su responsabilidad civil en los términos establecidos en el artículo 110 (restitución, reparación del daño e indemnización de perjuicios materiales y morales) y de forma solidaria con las personas físicas que fueren condenadas por los mismos hechos. Esta disposición puede llegar a tener particular trascendencia en los supuestos de corrupción privada ${ }^{76}$.

En el ámbito de la corrupción en el sector público, los perjudicados por actos de corrupción de autoridades y funcionarios públicos pueden también reclamar la responsabilidad patrimonial de la Administración por el mal funcionamiento de sus servicios a raíz de la omisión del deber "in vigilando" de sus funcionarios, autoridades y personal laboral ${ }^{77}$. Asimismo, el Art. 121 del mismo Código Penal español, establece,

74 IZQUIERDO TOLSADA, M., "La responsabilidad civil en el proceso penal", en REGLERO CAMPOS, F., (Coord.), Tratado de Responsabilidad Civil, cit., p. 446. Ampliamente, sobre la responsabilidad civil derivada del delito, vid. Quintero Olivares, G., Cavanillas Múuica, S., Llera SuÁrez-BÁrcena, E., La responsabilidad civil ex delicto, Aranzadi, Pamplona, 2002.

75 Sin embargo, no parece que esta norma pueda aplicarse al caso de la corrupción privada, pues parece pensada para actos delictivos cometidos por los gestores y representantes en el desarrollo de la actividad ordinaria de la empresa, y no para los actos de corrupción activa o pasiva en las relaciones con la Administración o con otras empresas.

76 Para los casos en que las personas jurídicas carezcan de patrimonio suficiente o se hayan vaciado de patrimonio ante las sospechas de una posible investigación criminal, resultará de particular importancia el mecanismo jurisprudencial del levantamiento del velo para dar respuesta a aquellos supuestos en que el responsable último de un perjuicio patrimonial fruto de actos de corrupción sean uno o varios de los socios de la entidad que no realizan labores de administración y que incluso puede que ni siquiera figuren formalmente como socios del ente, aunque de hecho sean los verdaderos dominus societatis, es decir, las personas de cuya voluntad dependen los actos de la sociedad. En tales casos se puede levantar el velo de la personalidad jurídica, penetrando en su substrato, para hacer responsable directo de los daños producidos directa o indirectamente por la sociedad (responsabilidad civil ex delicto) al sujeto (socio oculto) o sujetos que resulten ser los responsables últimos de las decisiones societarias perjudiciales para terceros. Vid. la completa obra de BOLDÓ RODÁ, C., Levantamiento del velo y persona jurídica en el Derecho privado español, $4^{\mathrm{a}}$ ed., Thomson-Aranzadi, Navarra, 2006.

77 Vid. en España los arts. 139 a 146 de la Ley 30/1992, de 26 de noviembre, sobre Régimen Jurídico de las Administraciones Públicas y Procedimiento Administrativo Común, modificados por el RD 429/1993, de 26 de marzo, por el que se aprueba el Reglamento de los Procedimientos de 
en relación con los delitos cometidos por autoridades y funcionarios públicos, que las distintas Administraciones públicas responden subsidiariamente de los daños causados por los penalmente responsables de los delitos dolosos o culposos, cuando éstos sean autoridad, agentes y contratados de la misma o funcionarios públicos en el ejercicio de sus cargos o funciones siempre que la lesión sea consecuencia directa del funcionamiento de los servicios públicos que les estuvieren confiados, sin perjuicio de la responsabilidad patrimonial derivada del funcionamiento normal o anormal de dichos servicios exigible conforme a las normas de procedimiento administrativo, y sin que, en ningún caso, pueda darse una duplicidad indemnizatoria; añade que si se exigiera en el proceso penal la responsabilidad civil de la autoridad, agentes y contratados de la misma o funcionarios públicos, la pretensión deberá dirigirse simultáneamente contra la Administración o ente público presuntamente responsable civil subsidiario ${ }^{78}$.

Obsérvese que tanto la responsabilidad civil derivada de los delitos contra la Administración pública como la responsabilidad patrimonial de la Administración, reconocen el derecho a la indemnización siempre que el daño producido se deba al funcionamiento normal o anormal de los servicios públicos. Podría discutirse aquí si el concepto de servicios públicos debe interpretarse restrictivamente, para referirse únicamente a los daños derivados del funcionamiento de servicios públicos a los ciudadanos o si, por el contrario, debe interpretarse en sentido amplio para incluir, por ejemplo, la adjudicación caprichosa e ilícita de contratos con la Administración a determinadas empresas a cambio de dádivas, beneficios o ventajas económicas de cualquier clase. De acuerdo con las obligaciones asumidas por España en los ya citados Convenio del Consejo de Europa de Derecho Civil sobre Corrupción (Art. 5) y Convención de Naciones Unidas sobre Corrupción (Art. 35), se entiende que debería interpretarse ampliamente el concepto de servicio público para dar cabida a la indemnización por daños derivados por actos de corrupción en los servicios de adjudicación de contratos.

Finalmente, los perjudicados podrán también recurrir a los mecanismos de responsabilidad previstos con carácter general por el ordenamiento jurídico-civil: la responsabilidad civil contractual (Art. 1101 del Código Civil español) y, sobre todo, la responsabilidad extracontractual o aquiliana (Arts. 1902 y ss. del Código Civil

las Administraciones Públicas en materia de Responsabilidad Patrimonial. Vid., entre otras, las obras de GONZÁLEZ PÉREZ, J., Responsabilidad Patrimonial de las Administraciones Públicas, Civitas, Madrid, 1996; MEDINA ALCOZ, L., La responsabilidad patrimonial por acto administrativo: aproximación a los efectos resarcitorios de la ilegalidad, la morosidad y la deslealtad desde una revisión general del sistema, Thomson-Civitas, Madrid, 2005; MARTÍNEZ REBOLLO, L., La responsabilidad patrimonial de las entidades locales, Iustel, Madrid, 2005; LÓPEZ GOÑI, M., Responsabilidad patrimonial de la administración pública: daños personales y quantum indemnizatorio, Thomson-Aranzadi, Navarra, 2007.

78 Cfr., Art. 146 de la Ley 30/1992, de 26 de noviembre, sobre Régimen Jurídico de las Administraciones Públicas y Procedimiento Administrativo Común. 
español); instrumento de gran versatilidad -a pesar de su lacónica redacción legalque está en la base de muchas de las acciones específicas de resarcimiento por daños y perjuicios previstas en la legislación especial ${ }^{79}$.

Se ve, en definitiva, cómo las acciones civiles de indemnización de daños y perjuicios forman parte del Derecho contra la corrupción, pudiendo tener una especial incidencia en la satisfacción de los sujetos perjudicados por actos de corrupción (sea pública o privada), habitualmente postergados en la represión penal y administrativa de la corrupción. Sin embargo, la amplitud de términos con que se expresan el Convenio del Consejo de Europa de Derecho Civil sobre Corrupción y la Convención de Naciones Unidas sobre Corrupción deja sin determinar si los mecanismos de indemnización por daños y perjuicios derivados de actos de corrupción estarán a disposición únicamente de los sujetos directamente perjudicados (como los competidores que no han podido obtener un contrato con una Administración pública o con una empresa privada por haber sido sobornados funcionarios públicos o directivos de la empresa para favorecer injustamente a un tercero), o si también podrán valerse de esos mecanismos los sujetos indirectamente perjudicados (como pueden ser los propios socios o accionistas, los trabajadores y los acreedores de la empresa beneficiaria de los actos de corrupción gestionados por sus administradores y que, como consecuencia de los mismos, resulte condenada por un delito de corrupción pública o privada y sancionada con penas de multa, suspensión temporal de actividades e incluso la disolución, además de la responsabilidad civil subsidiaria derivada del delito).

Por lo que se refiere a los sujetos directamente perjudicados por actos de corrupción, destapado el soborno y condenados penalmente los sujetos activos y pasivos de la corrupción; esto es, bien la autoridad o funcionario público que aceptó un soborno o que influyó en otro para favorecer con su decisión a una empresa frente a otras en una licitación pública, así como el administrador o representante de una empresa o entidad privada que ofrece el soborno a ese agente público ${ }^{80}$, como, por otro lado, el administrador, director, empleado o colaborador de la empresa privada que ofreció y/o aceptó un soborno para favorecer a una empresa frente a otras en la adjudicación de un contrato ${ }^{81}$, así como, en su caso, las propias empresas personas jurídicas beneficiarias directas del acto de corrupción o soborno activo y/o pasivo en el sector público o en el sector privado $^{82}$; destapado el soborno, decimos, y

79 Uno de los últimos y más completos estudios sobre la responsabilidad civil es el de REGLERO CAMPOS F., (Coord.), Tratado de Responsabilidad Civil, Thomson-Aranzadi, Navarra, 2008.

80 Delitos de cohecho (ex Arts. 419 a 427 del Código Penal español) o de tráfico de influencias (ex Arts. 428 a 431 del Código Penal español).

81 Delito de corrupción entre particulares (ex Art. 286 bis del Código Penal español).

82 Imputación de responsabilidad penal a las personas jurídicas por los delitos de cohecho o tráfico de influencias o de corrupción privada cometidos en nombre y por cuenta de las mismas y en su provecho por sus representantes legales o administradores de hecho o de derecho (ex Art. 31 bis del Código Penal español). 
condenadas penalmente las personas físicas responsables directas del mismo y en su caso las personas jurídicas beneficiarias en los delitos de corrupción, la cuestión es si los perjudicados por esos actos de corrupción pública o privada, además de la posibilidad de reclamar indemnizaciones por daños y perjuicios a los responsables directos de los actos de corrupción (esto es, la autoridad o funcionario público que acepta el soborno en la corrupción pública y el administrador, director, empleado o colaborador de una empresa que ofrece y/o acepta el soborno en la corrupción en el sector privado), podrán también dirigirse, para resarcirse de los daños y perjuicios padecidos por esos actos, contra la Administración responsable del nombramiento y vigilancia del agente público o contra la empresa responsable del nombramiento y vigilancia del administrador, director, empleado o colaborador que ofreció el soborno y que acabó beneficiándose del acto de corrupción, así como, en su caso, contra la empresa responsable del nombramiento y vigilancia del administrador, director, empleado o colaborador que solicitó o aceptó el soborno por parte de los representantes de otra empresa o entidad privada, en ambos casos, claro está, cuando el ofrecimiento y la aceptación del soborno se hubiera hecho por los administradores o empleados en nombre e interés de la empresa ${ }^{83}$.

Esta cuestión, como hemos visto, parece satisfactoriamente resuelta en la actualidad con la posibilidad de exigir responsabilidad civil subsidiaria a la Administración en los delitos contra la Administración pública (Art. 121 del Código Penal español) cometidos por funcionarios públicos, sin perjuicio, además de la posibilidad de exigir directamente la responsabilidad patrimonial de la Administración (aunque en ningún caso puede darse una duplicidad indemnizatoria). Lo mismo puede decirse, en el ámbito de la corrupción activa y pasiva en la empresa privada, sea para corromper a un funcionario público (cfr., Arts. 423 y 429 del Código Penal español y Art. 445 del mismo Código Penal en los delitos de corrupción en las transacciones comerciales internacionales) o al representante de otra empresa o entidad privada (cfr., Art. 286bis del Código Penal español que tipifica el delito de corrupción entre particulares), tras el reconocimiento reciente de la responsabilidad penal -y la consiguiente responsabilidad civil subsidiaria- de las personas jurídicas en muchos ordenamientos europeos, entre ellos el español (cfr., Arts. 31bis y 116.3 del Código Penal español). No obstante, parece necesario concretar algunos aspectos difusos en

83 Es claro que el ofrecimiento de un soborno por el administrador o empleado de una empresa privada a una autoridad o funcionario público o al administrador o empleado de otra empresa privada para conseguir la adjudicación de un contrato de compraventa de mercancías o prestación de servicios puede beneficiar claramente a la empresa vendedora o prestadora del servicio. En cuanto al administrador o empleado de la empresa adjudicataria del contrato, es muy posible que éste solicite o acepte el soborno en su propio nombre e interés, actuando incluso contra los intereses de la empresa que representa (lo que constituye un caso claro de administración desleal), pero no puede descartarse que esos sobornos se acepten en provecho de la propia empresa representada excluyendo así de antemano a otros posibles oferentes e ingresando el precio del soborno en las arcas de la empresa maquillado bajo alguna operación simulada paralela. 
el capítulo de la exigencia de indemnización por daños y perjuicios a la empresa o entidad beneficiaria de los actos de corrupción.

Así, en primer lugar, una empresa o persona jurídica sólo resultará penal y -subsidiariamente- civilmente responsable cuando el acto de corrupción activa (ofrecer un soborno) o pasiva (recibir un soborno) sea cometido por sus representantes legales y administradores de hecho o de derecho o por directores, empleados o colaboradores sometidos a la autoridad de aquellos "en nombre o por cuenta de la misma" (cfr., Art. 31bis, apartado 1 y Art. 116.3 del Código Penal español). Dicho de otra forma, los actos de corrupción cometidos en la empresa privada por sus administradores, directores, empleados o colaboradores deben realizarse en interés de la empresa para poder imputar a ésta la responsabilidad penal y civil correspondiente como beneficiaria de los mismos. Este factor puede ser más fácil de demostrar en los casos de corrupción activa (Art. 286bis apartado 1 en relación con el Art. 31bis apartado 1 del Código Penal español), ya que en este caso normalmente los administradores o representantes ofrecen un soborno para conseguir un contrato de adquisición o venta de mercancías o un contrato de servicios para la empresa. Sin embargo, en los casos de corrupción pasiva (Art. 286bis apartado 2 en relación con el art. 31bis apartado 1 del Código Penal español) no será común que el administrador, director, empleado o colaborador de una empresa o entidad solicite, acepte o reciba un soborno en forma de beneficio o ventaja de cualquier naturaleza a cambio de favorecer al que se lo otorga en detrimento de terceros para favorecer a su propia empresa, sino más bien en su propio beneficio personal. De hecho, la mera circunstancia de recibir sobornos para favorecer a un tercero en la contratación de bienes o servicios constituye casi siempre un acto de administración desleal, ya que se interpone el interés particular del administrador o representante frente al interés de la empresa, llegando ésta frecuentemente a resultar perjudicada en tanto en cuanto, como consecuencia del soborno, el contrato celebrado contiene peores condiciones que el ofrecido por terceros competidores postergados al interponerse el soborno ${ }^{84}$. En segundo lugar,

84 En cuyo caso, el administrador que interpone su interés personal -o el de un tercero vinculado a él por cualquier lazo- al interés de la empresa (normalmente una sociedad de capital) estaría infringiendo los deberes legales de administración diligente y de lealtad para con el interés social (cfr., Arts. 225.1 y 226 LSC), por lo que podría ser objeto de una acción social de responsabilidad promovida por la propia sociedad, por accionistas minoritarios o, subsidiariamente, por los acreedores de la sociedad (cfr., Arts. 236-240 LSC). Naturalmente, también podría ser perseguido por la vía penal a través del delito societario de administración desleal, según el cual, los administradores de hecho o de derecho o los socios de cualquier sociedad constituida o en formación, que en beneficio propio o de un tercero, con abuso de las funciones propias de su cargo, dispongan fraudulentamente de los bienes de la sociedad o contraigan obligaciones a cargo de ésta causando directamente un perjuicio económicamente evaluable a sus socios, depositarios, cuenta-partícipes o titulares de los bienes, valores o capital que administren, serán castigados con la pena de prisión de seis meses a cuatro años, o multa del tanto al triplo del beneficio obtenido (cfr., Art. 295 CP). Los anterior, además, sin descartar, que por medio de esos contratos forzados por sobornos el administrador o representante de la empresa que recibe el soborno proceda a la venta de activos de dicha empresa a precios 
la indemnización por daños y perjuicios presenta importantes problemas de prueba de los daños y perjuicios realmente sufridos. Así: ¿El simple hecho de acceder a un concurso o licitación pública supone una inversión susceptible de reclamación por daños y perjuicios o solamente es una inversión imprescindible para conseguir una mera expectativa de negocio que haría difícil la prueba de un daño concreto? En el caso de la adjudicación de contratos por una empresa privada a otra empresa privada previa mediación de un soborno para excluir a terceros competidores: ¿Podrían éstos exigir daños y perjuicios en concepto de lucro cesante acreditando objetivamente la mayor pertinencia de su oferta?

Más compleja es la respuesta pertinente para la segunda cuestión planteada al principio: la posibilidad de resarcir por la vía de la responsabilidad civil los daños indirectos o reflejos de actos de corrupción. En estos casos: ¿Cabe pensar en la posibilidad de que la persona jurídica (normalmente una sociedad mercantil de capital) considerada responsable penal y civilmente (ex Arts. 31bis y 116.2 del Código Penal español) por delitos de corrupción pública o privada, pudiera luego ejercitar una acción de responsabilidad contra los administradores que gestionaron el soborno de un agente público o del administrador o representante de otra empresa o entidad privada? Más aún: ¿Podría admitirse el ejercicio de acciones de responsabilidad individual contra los administradores de empresas privadas promovidas por socios o por terceros cuyos intereses patrimoniales resultaren insatisfechos indirectamente por la despatrimonialización de la entidad subsiguiente a las sanciones penales y civiles asociadas a delitos de corrupción en el ámbito público o privado?

Pues bien, parece que en estos casos los posibles daños padecidos por la sociedad y por los socios y terceros (acreedores, inversores, trabajadores) tendrían lugar, en su caso, indirectamente, con motivo de las sanciones penales y de la responsabilidad civil subsidiaria derivadas de la imputación de un delito de corrupción pública (cohecho, tráfico de influencias, corrupción de agentes extranjeros) o privada a la empresa beneficiaria del soborno gestionado por esos administradores. Efectivamente, de acuerdo con lo previsto en el art. 33.7 del Código Penal español, el castigo penal que se puede imponer a una persona jurídica puede ir desde multas por cuotas o proporcionales hasta la disolución de la persona jurídica, pasando por

inferiores a los de mercado, despatrimonializando así gravemente a la entidad y perjudicando directamente a socios, trabajadores, inversores y acreedores. En estos casos no se aplica el delito de corrupción entre particulares, pues esa operación no parece entrar dentro de los márgenes del tipo penal tal y como aparece definido en el art. 286bis CP, ya que éste habla de recibir, solicitar o aceptar un beneficio o ventaja no justificados con el fin de favorecer a quien se lo otorga frente a terceros (se entiende que competidores, ajenos a su propia empresa), en relación con la adquisición o venta de mercancías o la contratación de servicios profesionales, y no, como aquí comentamos, con la venta de activos materiales o inmateriales de su empresa. Por lo tanto, estos casos de corrupción de administradores y directores dentro de la propia empresa, recibiendo sobornos a cambio de lesionar el interés de la empresa, tendrán que reconducirse a otros tipos penales, como puede ser la apropiación indebida (art. 252 CP) o, sobre todo, el delito de administración desleal (Art. 295 CP). 
la suspensión temporal de sus actividades, la clausura temporal de sus locales y establecimientos, la prohibición para realizar en el futuro las actividades en cuyo ejercicio se hubiera cometido, favorecido o encubierto el delito o la inhabilitación para recibir subvenciones y ayudas públicas o para contratar con el sector público y gozar de beneficios o incentivos fiscales o de la Seguridad Social; por eso, se comprende perfectamente que cualquiera de estas sanciones penales, además de la responsabilidad civil derivada del delito (Art. 116.3 del Código Penal español), puede afectar de manera grave o importante al patrimonio de la empresa e incluso a su propia subsistencia en el mercado y, con ello, indirectamente, a los intereses de los socios, accionistas o asociados, de los trabajadores, de los inversores y de los acreedores. De ahí que resulte fundamental preguntarse sobre la posibilidad de resarcirse de los daños provocados indirectamente por actos de corrupción y, en caso de admitirse, sobre los mecanismos de que dispone el ordenamiento jurídico para canalizar las reclamaciones de daños y perjuicios. La respuesta puede encontrarse en la normativa sobre responsabilidad de administradores de sociedades de capital y de otras organizaciones personificadas, como cooperativas, asociaciones y fundaciones.

El Art. 236 del Texto Refundido de la Ley de Sociedades de Capital (LSC) declara con carácter general que los administradores de derecho o de hecho como tales $^{85}$, responderán frente a la sociedad, socios y acreedores sociales, del daño que causen por actos u omisiones contrarios a la Ley o a los estatutos o por los realizados al incumplir los deberes inherentes al desempeño, sin que en ningún caso exonere de esa responsabilidad la circunstancia de que el acto o acuerdo lesivo haya sido adoptado, autorizado o ratificado por la junta general de $\operatorname{socios}^{86}$.

85 Son administradores de hecho aquellos cuyo nombramiento hubiera caducado pero siguen de hecho en el ejercicio del mismo y también los que sin haber sido nombrados formalmente como administradores se ocupan de hecho de la gestión societaria, ocupando el cargo formalmente testaferros o personas de confianza que siguen sus instrucciones. Vid. DÍAZ ECHEGARAY, J.L., El Administrador de Hecho de las Sociedades, Aranzadi, Navarra, 2002. Vid. también, PERDICES HUETOS A., "Significado actual de los administradores de hecho: los que administran de hecho y los que de hecho administran", RDS, 2002-1, pp. 277 y ss. De acuerdo con el original enunciado de este autor, los administradores con cargo caducado que siguen ejerciendo el mismo "administran de hecho", mientras que los administradores ocultos o en la sombra ("shadow directors") son los que "de hecho administran".

86 El Art. 43 de la Ley 27/1999, de 16 de julio, de Cooperativas se remite, con algunos matices, al régimen de responsabilidad de las sociedades anónimas, incorporadas ahora dentro del nuevo Texto Refundido de la Ley de Sociedades de Capital. Por su parte, la Ley Orgánica 1/2002, de 22 de marzo, reguladora del Derecho de Asociación, establece en su art. 15.3 que los miembros o titulares de los órganos de gobierno y representación, y las demás personas que obren en nombre y representación de la asociación, responderán ante ésta, ante los asociados y ante terceros por los daños causados y las deudas contraídas por actos dolosos, culposos o negligentes. Por su parte, la Ley 50/2002, de 26 de diciembre, de Fundaciones, dispone que los patronos de una fundación responderán solidariamente frente a la fundación de los daños y perjuicios que causen por actos contrarios a la Ley o a los Estatutos, o por los realizados sin la diligencia con la que deben desempeñar el cargo. Quedarán exentos de responsabilidad quienes hayan votado en contra del 
Todos los miembros del órgano de administración que hubiera adoptado el acuerdo o realizado el acto lesivo responderán solidariamente, salvo los que prueben que, no habiendo intervenido en su adopción y ejecución, desconocían su existencia o, conociéndola, hicieron todo lo conveniente para evitar el daño o, al menos, se opusieron expresamente a aquél (Art. 237 LSC). La Ley reconoce así, por un lado, la acción social de responsabilidad contra los administradores sociales, que podrá entablarse por la propia sociedad previo acuerdo de la junta general (Art. 238 LSC), también por la minoría de socios que represente al menos el 5\% del capital social en defensa del interés social, si, habiendo solicitado la convocatoria de la junta general para decidir en su caso sobre el ejercicio de la acción social de responsabilidad, los administradores no la hubieren convocado o, convocada, la junta hubiera decidido no adoptar ese acuerdo o si, habiéndolo adoptado, la acción de responsabilidad no se hubiera entablado dentro del plazo de un mes desde la adopción del mismo (Art. 239 LSC), e incluso subsidiariamente por los acreedores sociales cuando la acción social de responsabilidad no hubiera sido ejercitada por la propia sociedad o por sus socios minoritarios, siempre que el patrimonio social resulte insuficiente para la satisfacción de sus créditos (Art. 240 LSC). Por otro lado, la Ley reconoce la acción individual de responsabilidad por daños y perjuicios a favor de socios y terceros por actos de los administradores que lesionen directamente sus intereses. Asimismo, en el terreno penal, el Art. 295 del Código Penal español establece que los administradores de hecho o de derecho o los socios de cualquier sociedad constituida o en formación, que en beneficio propio o de un tercero, con abuso de las funciones propias de su cargo, dispongan fraudulentamente de los bienes de la sociedad o contraigan obligaciones a cargo de ésta causando directamente un perjuicio económicamente evaluable a sus socios, depositarios, cuenta-partícipes o titulares de los bienes, valores o capital que administren, serán castigados con la pena de prisión de seis meses a cuatro años, o multa del tanto al triplo del beneficio obtenido.

Parece, entonces, que difícilmente podría prosperar una acción individual de responsabilidad dirigida contra los administradores de sociedades de capital o una querella criminal por el delito de administración desleal con motivo de los daños provocados indirectamente por actos de corrupción pública o privada promovidos por esos administradores que deriven en condenas penales y civiles para la persona jurídica que determinen su empobrecimiento patrimonial y, con él, el de sus socios y acreedores. Aunque podría discutirse sobre si esos daños experimentados por socios y acreedores con motivo del empobrecimiento patrimonial y financiero de la sociedad asociado a las sanciones penales y responsabilidad civil por delitos de corrupción tienen carácter "indirecto" o se pueden interpretar, por el contrario, como un daño "directo" de sus intereses.

acuerdo, y quienes prueben que, no habiendo intervenido en su adopción y ejecución, desconocían su existencia o, conociéndola, hicieron todo lo conveniente para evitar el daño o, al menos, se opusieron expresamente a aquel. 
Sea como fuere, parece que sí podría resultar viable la acción social de responsabilidad contra los administradores, ejercitada bien por la propia sociedad previo acuerdo de la Junta General de socios o accionistas, o bien por los accionistas minoritarios o por los acreedores en los casos previstos en la Ley. Y ello independiente de la naturaleza "indirecta" o "directa" que se atribuya al daño sufrido por la sociedad como consecuencia de las sanciones derivadas de delitos de corrupción.

No obstante, en este segundo caso, es preciso plantearse y determinar si un acto de corrupción cometido por los administradores sociales en nombre o provecho de la empresa social y que deriva en la adjudicación de un contrato o cualquier otro beneficio o ventaja para la sociedad, puede interpretarse posteriormente como un perjuicio para la sociedad. Es decir: ¿Tendrían argumentos suficientes la sociedad o sus socios para, por ejemplo, interponer una acción social de responsabilidad contra ellos cuando la sociedad e indirectamente los socios se hubiesen lucrado significativamente como consecuencia de la actuación ilícita de aquellos al sobornar a funcionarios públicos a los administradores o representantes de otras entidades privadas?

Habría que valorar la cuantía de las sanciones penales a personas jurídicas y las derivadas de la responsabilidad civil subsidiaria, así como las pérdidas patrimoniales y de imagen producidas con motivo de las sanciones penales (sanciones económicas, suspensión temporal de actividades y cierre de establecimientos, disolución de la empresa social y demás, ex Art. 33.7 del Código Penal español). Desde luego es muy posible que el beneficio obtenido por la corrupción de agentes públicos o administradores de otras empresas privadas supere con creces los posibles perjuicios derivados más tarde de la condena penal y responsabilidad civil subsidiaria de la persona jurídica por delitos de corrupción en el sector público o privado. Pero puede darse la situación contraria y que los efectos de la condena superen los beneficios obtenidos en su día con la corrupción. Sin embargo, no parece que estos factores cuantitativos puedan resultar determinantes. Aun en el caso de que los beneficios por la sociedad y por sus socios o accionistas obtenidos hubieran sido superiores, el patrimonio y la imagen de la sociedad podría verse deteriorada significativamente por la corrupción en que se vio implicada y ello podría bastar para justificar acciones de responsabilidad civil contra los administradores por vulnerar los intereses de la sociedad ${ }^{87}$.

Tampoco pueden resultar determinantes el conocimiento de la existencia de sobornos por parte de la totalidad o mayoría de los socios de la sociedad e incluso la ratificación expresa o tácita de los mismos. El Art. 236.2 LSC es muy claro al indicar que en ningún caso exonerará de responsabilidad la circunstancia de que el acto o acuerdo lesivo haya sido adoptado, autorizado o ratificado por la junta general de la sociedad. Ello se debe a que los administradores ocupan una posición autónoma

87 Vid. en el ámbito penal el artículo de GÓMEZ-BENíTEZ, J.M., "Corrupción y delito de administración desleal", Diario La Ley, 1999. 
dentro de la organización societaria, con sus propias competencias no sometidas a las instrucciones de la Junta General de socios, por lo que su régimen de responsabilidad no depende en ningún momento de la autorización o ratificación de sus actuaciones por la Junta.

Es decisivo, entonces, valorar los daños producidos como consecuencia de los actos de los administradores en el momento en que se constatan, ya que una sociedad tiene una base subjetiva o accionarial cambiante (cambios constantes de socios), como es cambiante la propia estructura subjetiva del órgano de administración al sustituir unos administradores por otros; $\mathrm{y}$, en todo caso, los terceros acreedores no tienen por qué verse perjudicados por las decisiones que pudieran tomar los administradores e incluso los propios socios de la entidad y que a la postre acaben derivando en un empobrecimiento de la estructura patrimonial y financiera de la organización que haga inviables los pagos e incluso su propia continuidad en el tráfico.

Los modernos ordenamientos europeos sobre sociedades de capital se caracterizan cada vez más por su trazado institucional; esto es, por tratarse de un sistema de disposiciones normativas orientado a la tutela no sólo de los intereses de los socios, sino de los intereses propios de la sociedad como organización autónoma de la empresa y de todos los intereses convergentes en la misma, sean de socios ("shareholders") o sean de inversores, acreedores y trabajadores ("stakeholders") ${ }^{88}$. De modo que cualquier acto u omisión de los administradores sociales de derecho o de hecho contrario a la Ley o a los estatutos o que incumplan los deberes inherentes al cargo causando un daño a la sociedad, podría derivar en el ejercicio de una acción social de responsabilidad contra ellos por la propia sociedad (a través de un acuerdo de la Junta General), por los accionistas minoritarios que representen al menos el cinco por ciento del capital social o, subsidiariamente, por los acreedores sociales que no pudieran cobrar sus créditos por el empobrecimiento del patrimonio social. Y, a la vista de lo expuesto con anterioridad, parece claro que el ofrecimiento de beneficios o ventajas económicas de cualquier naturaleza a una autoridad o funcionario público o a los administradores, directores, empleados o colaboradores de empresas privadas constituyen actos contrarios a la Ley, al tratarse de delitos tipificados en el Código Penal.

Se entiende además que esta interpretación favorable a incluir los daños indirectos dentro de las indemnizaciones exigibles por actos de corrupción pública o privada, se corresponde con el objetivo de plena satisfacción o justicia restaurativa que desgranan tanto el Convenio del Consejo de Europa de Derecho Civil sobre Corrupción como la Convención de Naciones Unidas sobre Corrupción, ambos ratificados por el Reino de España.

88 El Art. 240 LSC, que legitima a los acreedores sociales para ejercer subsidiariamente la acción social de responsabilidad cuando el patrimonio social resulte insuficiente para la satisfacción de sus créditos, constituye una buena prueba de ello. 
También pueden considerarse actos de corrupción en el sector privado en sentido amplio los abusos de información privilegiada y alteración de precios sobre valores negociables en mercados de valores (cfr., Arts.81, 83bis y 83ter de la Ley 24/1988, de 28 de julio, del Mercado de Valores).

Estos comportamientos son sancionables en vía administrativa por la propia legislación de mercado de valores (cfr., Arts. 100 y 103 LMV), pero además pueden ser constitutivos de delito (dentro de la categoría de los delitos contra el mercado, al igual que el delito de corrupción entre particulares) si de forma directa o por persona interpuesta se usa de alguna información relevante para la cotización de cualquier clase de valores o instrumentos negociados en algún mercado organizado, oficial o reconocido, a la que se haya tenido acceso reservado con ocasión del ejercicio de su actividad profesional o empresarial, o se suministra a terceros obteniendo para sí o para un tercero un beneficio económico superior a 600.000 euros o causando un perjuicio de idéntica cantidad, siendo castigado con la pena de prisión de uno a cuatro años, multa del tanto al triplo del beneficio obtenido o favorecido e inhabilitación especial para el ejercicio de la profesión o actividad de dos a cinco años (Art. 285 del Código Penal español). Igualmente podrá aplicarse la responsabilidad civil derivada del delito (Arts. 109 CP español). Pero, independientemente de la posible responsabilidad penal o administrativa que pudiera imputarse a quien se prevalga de información privilegiada o altere artificialmente los precios en mercados de valores en beneficio propio o de un tercero, ¿Podrían los inversores directa o indirectamente perjudicados por un abuso de información privilegiada en la compraventa de acciones dirigirse civilmente contra el responsable de esos comportamientos y ejercitar acciones de responsabilidad contractual o extracontractual? ${ }^{89}$.

Por último, un caso singular de corrupción en la empresa privada lo constituye el ofrecimiento de sobornos en forma de beneficios o ventajas de cualquier clase a auditores de cuentas, así como la solicitud, recepción o aceptación de esos beneficios o ventajas por éstos, a cambio de favorece frente a terceros a quien le ofrece el beneficio o ventaja, incumpliendo con sus obligaciones en la prestación de servicios profesionales. Podría discutirse si estos comportamientos pueden encajar o no en el delito de corrupción entre particulares del Art. 286bis del Código Penal español ${ }^{90}$, a partir siempre del principio de mínima intervención del Derecho penal que obliga a realizar interpretaciones restrictivas del tipo penal. Pero no cabe duda que esos comportamientos pueden calificarse en sentido amplio como actos de corrupción en

89 Vid. el interesante trabajo de MARTÍNEZ FLÓREZ, A., "En torno a la responsabilidad frente a los inversores de quien utiliza información privilegiada en los mercados de valores", en AA.VV., Estudios en Homenaje al Profesor Aurelio Menéndez Menéndez, T. III, Civitas, Madrid, 1996, pp. 3355 y ss.

90 A los fines de encajar estas conductas en el delito de corrupción entre particulares del Art. 286 bis $\mathrm{CP}$, podría defenderse que los auditores actúan como colaboradores de la empresa mercantil, pues son profesionales independientes que prestan un servicio a la empresa pero colaboran de alguna manera con ella en la verificación de sus cuentas anuales. 
el sector privado, pues alteran las necesarias condiciones de transparencia contable exigidas además por normativa internacional y nacional, pudiendo causar graves trastornos a los accionistas, inversores, trabajadores y acreedores de una empresa, como demostró en su día palmariamente el caso Enron-Andersen.

De ahí que quienes pudieran resultar perjudicados por una verificación contable dolosa o culposamente defectuosa tengan la posibilidad de resarcirse de los daños y perjuicios padecidos acudiendo a las acciones de responsabilidad civil previstas por el ordenamiento contra los Auditores de Cuentas. En concreto, el Art. 11 de la Ley de Auditoría de Cuentas de 1988 (reformada por la Ley 12/2010) establece con carácter general que los auditores de cuentas y las sociedades de auditoría responderán por los daños y perjuicios que se deriven del incumplimiento de sus obligaciones según las reglas generales del Código Civil, si bien dicha responsabilidad será exigible de forma proporcional a la responsabilidad directa por los daños y perjuicios económicos que pudieran causar por su actuación profesional, excluidos los daños y perjuicios causados, en su caso, por la propia sociedad auditada o por un tercero. Cuando -como es habitual- la auditoría de cuentas se realice por un auditor de cuentas en nombre de una sociedad de auditoría, responderán solidariamente tanto el auditor que haya firmado el informe de auditoría como la propia sociedad.

Esta amplísima responsabilidad legitimaría entonces a los socios, inversores y acreedores sociales que sufrieran algún tipo de daño como consecuencia de la falsa apariencia de normalidad, liquidez, saneamiento patrimonial o solvencia que pudiera transmitir un informe de auditoría falseado sobre la situación de una concreta empresa, para exigir la pertinente responsabilidad por daños y perjuicios a los auditores personas físicas firmantes del informe y, en su caso, a la sociedad de auditoría en cuyo nombre hubiera actuado el auditor.

\section{$* * *$}

Lo que subyace a fin de cuentas en la multiplicidad de mecanismos penales, administrativos y también civiles para prevenir y reprimir comportamientos de corrupción también en el sector privado, es, no sólo la obligación y firme intención de las instituciones internacionales y de los Estados miembros de las mismas de combatir esta lacra que lamentablemente caracteriza a la sociedad y a la economía modernas, sino también la posibilidad e incluso -podría decirse- el deber moral de todos aquellos que puedan sentirse perjudicados de hacer valer sus derechos contra los corruptos, pues de esta forma contribuirán decisivamente en último término a la lucha contra la degeneración de las instituciones y contra el fraude y el abuso en el ejercicio de las actividades económicas privadas. Las últimas reformas operadas en los campos del Derecho Penal, Administrativo, Civil y Mercantil para prevenir y reprimir estas conductas también en el sector privado, ofrecen ahora mecanismos adecuados para combatir estos comportamientos e incluso de obtener una adecuada satisfacción de los intereses económicos y morales lesionados como consecuencia de los mismos. 
Como dijera el excelso Rudolf Von IHERING en su legendaria obra "La Lucha por el Derecho":

\begin{abstract}
"El que se vea atacado en su derecho debe resistir; este es un deber que tiene para consigo mismo (...) Todo hombre está encargado dentro de su esfera, de guardar y de hacer ejecutar las disposiciones legales. El derecho concreto que él posee no es más que una autorización que tiene del Estado para combatir por la Ley en las ocasiones que le interesan, y de entrar en la lid para resistir a la injusticia (...). El hombre lucha, pues, por el derecho todo, defendiendo su derecho personal en el pequeño espacio en que lo ejerce. El interés y las demás consecuencias de su acción se extienden por el hecho mismo, más allá, fuera de su personalidad"91.
\end{abstract}

\title{
REFERENCIAS
}

AA.VV., Transformaciones del Derecho en la Mundialización, Estudios de Derecho Judicial, 16, 2000.

AA.VV., Derecho de Sociedades Anónimas Cotizadas, Thomson-Aranzadi, 2006; ANDRÉS IBÁÑEZ, P. (Edit.), Corrupción y Estado de Derecho. El papel de la jurisdicción, Madrid, 1996.

ARGANDOÑA, A., La Convención de las Naciones Unidas sobre la Corrupción y su impacto sobre las empresas internacionales, accesible en el sitio http://www. eben-spain.org/docs/Papeles/XIV/ARGANDOnA_ANTONIO.pdf.

ARPIO SANTACRUZ, J.L., Las Ayudas Públicas ante el Derecho europeo de la competencia, Aranzadi, Pamplona, 2000.

AZAUSTRE FERNÁNDEZ, Ma. J., El secreto Bancario, Bosch, Barcelona, 2001.

BERCOVITZ RODRÍGUEZ-CANO, A., Apuntes de Derecho Mercantil, 10 a ed., Thomson-Reuters Aranzadi, 2010.

BETANCOR, A., "Enron, liberalización, nueva economía”, Política Exterior, No. 26, 2002, pp. 59 y ss.

BLANCH, A. (Edit.), Luces y Sombras de la Globalización, Publicaciones de la Universidad Pontificia de Comillas ICADE, Madrid, 2000.

BOLDÓ RODÁ, C. Levantamiento del velo y persona jurídica en el Derecho privado español, 4a ed., Aranzadi, Madrid, 2006.

CÁMARA LAPUENTE, S., "El trust y la fiducia: posibilidades para una armonización europea”, en CÁMARA LAPUENTE S., (coord.), Derecho Privado Europeo, Colex, Madrid, 2003, pp. 1099 y ss.

91 VON IHERING, R., La Lucha por el Derecho, traducción española de A. POSADA Y BIESCA, Porrúa, México, 1998, pp. 29 y 67. 
CARBAJO CASCÓN. F., La sociedad de Capital Unipersonal, Aranzadi, Pamplona, 2002.

CUGAT MAURI, M., La Desviación del Interés General y el Tráfico de Influencias, Cedes, Barcelona, 1997.

D’ALBERTI, M., “Corruzione soggettiva e oggettiva”, en D’ALBERTI M Y FINOCCHI, R., Corruzione e Sistema Istituzionale, Il Mulino, Bologna, 1994, pp. 13 y ss.

DAVIGO, P., "Falso in bilancio, concussione e corruzione: l'esperienza giurisprudenziale", en MANNA, A. (a cura di), Falso in bilancio, concussione e corruzione: esperienze a confronto (Aspetti sostanziali e processuali), Acucci editore, Bari, 1998, pp. 21 y ss.

DE LA DEHESA, G., Comprender la Globalización, Alianza Editorial, Madrid, 2000

DE TORRES ZAPATERA, M., Valores ocultos en las cuentas anuales, Civitas, Madrid, 2002.

DEMETRIO CRESPO, E., "Corrupción y Delitos con la Administración Pública", en FABIÁN CAPARRÓS, E. (Coord.), La Corrupción: Aspectos Jurídicos y Económicos, Ratio Legis, Salamanca, 2000, pp. 68 y ss.

DÍAZ ECHEGARAY, J.L., El Administrador de Hecho de las Sociedades, Aranzadi, Navarra, 2002.

ESTEBAN VELASCO, G., (Coord.), El Gobierno de las Sociedades Cotizadas, McGraw Hill, Madrid, 1999.

FABIÁN CAPARRÓS, E., (Coord.), La Corrupción: Aspectos Jurídicos y Económicos, Ratio Legis, Salamanca, 2000.

FAVA, T., Do ut des (Genesi, evoluzione e crisi del sistema della corruzione), Carocchi, Roma, 1999.

FLORE, D., L'Incrimination de la Corruption (Lex nouveaux instruments internationaux. La nouvelle loi belge du 10 fèvrier 1999), La Charte, Bruxelles, 1999.

GARCÍA MEXÍA, P., Los Conflictos de Intereses y la Corrupción Contemporánea, Aranzadi, Colección Divulgación Jurídica, Pamplona, 2001.

GARCÍA-CRUCES GONZÁLEZ, J.A., Globalización Económica y Derecho Mercantil, Publicaciones de la Facultad de Derecho de la Universidad de Zaragoza, 2002.

GÓMEZ-BENÍTEZ, J.M., "Corrupción y delito de administración desleal”, La Ley, 1999; GONZÁLEZ CUSSAC, J.L, (Dir.), Financiación del terrorismo, blanqueo de capitales y secreto bancario, Tirant lo blanch, Valencia, 2009.

GONZÁLEZ PÉREZ J., Responsabilidad Patrimonial de las Administraciones Públicas, Civitas, Madrid, 1996.

GUILLÉN FERRER, Mª J., El Secreto Bancario y sus Límites Legales (Límites de Derecho Público), Tirant lo Blanch, Valencia, 1997 
HEIDENHEIMER A.J., JOHNSTON, M. y LEVINE, V.T., (Edits.), Political Corruption. A Handbook, Transaction, New Brunswick, 1989.

IZQUIERDO TOLSADA, M., "La responsabilidad civil en el proceso penal”, en REGLERO CAMPOS, F., (Coord.), Tratado de Responsabilidad Civil, $3^{\mathrm{a}}$ ed., Thomson-Aranzadi, Navarra, 2008, pp. 445 y ss.

KIMBERLY, A.E., (Edit.), Corruption and the Global Economy, Institute for International Economics", Washington DC, 1997.

LÓPEZ GOÑI, M., Responsabilidad patrimonial de la administración pública: daños personales y quantum indemnizatorio, Thomson-Aranzadi, Navarra, 2007.

MAGADÁN DÍAZ, M. y RIVAS GARCÍA, J., Corrupción y fraude: economía de la transgresión, Madrid, 1999.

MALEM SEÑA, J.F., Globalización, comercio internacional y corrupción, Gedisa, Barcelona, 2000.

MANNA, A. (a cura di), Falso in bilancio, concussione e corruzione: esperienze a confronto (Aspetti sostanziali e processuali), Acucci editore, Bari, 1998.

MARTÍNEZ FLÓREZ, A., "En torno a la responsabilidad frente a los inversores de quien utiliza información privilegiada en los mercados de valores", en AA.VV., Estudios en Homenaje al Profesor Aurelio Menéndez Menéndez, T. III, Civitas, Madrid, 1996, pp. 3355 y ss.

MARTÍNEZ REBOLLO, L., La responsabilidad patrimonial de las entidades locales, Iustel, Madrid, 2005.

MEDINA ALCOZ, L., La responsabilidad patrimonial por acto administrativo: aproximación a los efectos resarcitorios de la ilegalidad, la morosidad y la deslealtad desde una revisión general del sistema, Thomson-Civitas, Madrid, 2005.

PAMPLONA, A., "Corrupción corporativa y comportamiento oportunista: una perspectiva jurídica", accesible en el sitio http://www.contralacorrupcion.org/ $? p=29$

PENE VIDARI, F., "Trust e rapporti fiduciari tra propietá e contratto", en Rivista Critica del Diritto Privato, Septiembre 2001, pp. 295 y ss.

PERDICES HUETOS A., "Significado actual de los administradores de hecho: los que administran de hecho y los que de hecho administran", RDS, 2002-1, pp. 277 y ss.

QUINTERO OLIVARES, G., CAVANILlAS MÚJICA, S., LLERA SUÁREZ-BÁRCENA, E., La responsabilidad civil «ex delicto», Aranzadi, Pamplona, 2002.

REGLERO CAMPOS, F., (Coord.), Tratado de Responsabilidad Civil, $3^{\mathrm{a}}$ ed., Thomson-Aranzadi, Navarra, 2008

RIVERO ORTEGA, R., "Instituciones Jurídico-Administrativas y Prevención de la Corrupción”, en FABIÁN CAPARRÓS, E., La Corrupción: Aspectos Jurídicos y Económicos, Ratio Legis, Salamanca, 2000, pp. 39 y ss. 
ROSE-ACKERMAN, S., "Corruption an the Private Sector", en HEIDENHEIMER, A.J., JOHNSTON, M. y LEVINE, V.T. (Edits.), Political Corruption. A Handbook, cit., pp. 701 y ss.

VALCÁRCEL, D., "Enron: una brecha abierta en el Sistema", Política Exterior, No. 26, 2002.

VICENT CHULIÁ F., Introducción al Derecho Mercantil, 21 a ed., Tirant lo Blanch, Valencia, 2007.

VON IHERING R., La Lucha por el Derecho, traducción española de POSADA Y BIESCA, A., Porrúa, México, 1998.

WEBER, M., Economía y Sociedad, Fondo de Cultura Económica, Madrid, 1993.

ZANCHETTA, P.L., “Tangentopoli: entre perspectivas políticas y judiciales", en ANDRÉS IBÁÑEZ, P. (Edit.), Corrupción y Estado de Derecho. El papel de la jurisdicción, Madrid, 1996, pp. 85 y ss. 